\title{
DID CAPITAL REQUIREMENTS AND FAIR VALUE ACCOUNTING SPARK FIRE SALES IN DISTRESSED MORTGAGE-BACKED SECURITIES?
}

\author{
Craig B. Merrill \\ Taylor D. Nadauld \\ René M. Stulz \\ Shane Sherlund \\ Working Paper 18270 \\ http://www.nber.org/papers/w18270 \\ NATIONAL BUREAU OF ECONOMIC RESEARCH \\ 1050 Massachusetts Avenue \\ Cambridge, MA 02138 \\ August 2012
}

Merrill and Nadauld are at the Marriott School of Management, Brigham Young University, Sherlund is at the Federal Reserve Board, and Stulz is at the Fisher College of Business, Ohio State University, ECGI, and NBER. We thank seminar participants at Brigham Young University for helpful comments. The analysis and conclusions contained in this paper are those of the authors and do not necessarily reflect the views of the Board of Governors of the Federal Reserve System, its members, its staff, or the National Bureau of Economic Research.

NBER working papers are circulated for discussion and comment purposes. They have not been peerreviewed or been subject to the review by the NBER Board of Directors that accompanies official NBER publications.

(C) 2012 by Craig B. Merrill, Taylor D. Nadauld, René M. Stulz, and Shane Sherlund. All rights reserved. Short sections of text, not to exceed two paragraphs, may be quoted without explicit permission provided that full credit, including $(\mathcal{C}$ notice, is given to the source. 
Did Capital Requirements and Fair Value Accounting Spark Fire Sales in Distressed Mortgage-Backed Securities?

Craig B. Merrill, Taylor D. Nadauld, René M. Stulz, and Shane Sherlund

NBER Working Paper No. 18270

August 2012

JEL No. G22,G28,G32,M41

\begin{abstract}
Much attention has been paid to the large decreases in value of non-agency residential mortgage-backed securities (RMBS) during the financial crisis. Many observers have argued that the fall in prices was partly driven by decreased liquidity and fire sales. We investigate whether capital requirements and accounting rules at financial institutions contributed to the selling of RMBS at fire sale prices. For financial institutions subject to credit-sensitive capital requirements, capital requirements increase as an asset's credit becomes impaired. When accounting rules require such an asset's value to be marked-to-market and the fair value loss to be recognized in earnings, a capital-constrained firm can improve its capital position by selling the credit-impaired asset even if it has to accept a liquidity discount to do so. Using a sample of 5,014 repeat transactions of non-agency RMBS by insurance companies from 2006 to 2009 , we show that insurance companies that became more capital-constrained because of operating losses (uncorrelated with RMBS credit quality) and also recognized fair value losses sold comparable RMBS at much lower prices than other insurance companies during the crisis.
\end{abstract}

\author{
Craig B. Merrill \\ Department of Finance \\ Brigham Young University \\ Provo, UT 84602-3113 \\ Craig_Merrill@byu.edu \\ Taylor D. Nadauld \\ Department of Finance \\ Brigham Young University \\ Provo, Utah 84602 \\ taylor.nadauld@byu.edu
}

\author{
René M. Stulz \\ The Ohio State University \\ Fisher College of Business \\ 806A Fisher Hall \\ Columbus, OH 43210-1144 \\ and NBER \\ stulz_1@cob.osu.edu \\ Shane Sherlund \\ Federal Reserve Board \\ Mailstop 93 \\ 20th and C Streets, NW \\ Washington, DC, 20551 \\ shane.m.sherlund@frb.gov
}


A key fact of the financial crisis is the dramatic drop in value of structured finance securities. Many observers have argued that the drop in transaction prices exceeded the adverse change in the fundamental value of the higher priority securities and that the magnitude of the drop is partly explained by loss of liquidity and fire sales. ${ }^{1}$ In this paper we investigate whether capital requirements and accounting rules at financial institutions contributed to the selling of structured finance securities at fire-sale prices. As many of these securities were held by financial institutions, reductions in their value led to reduced levels of capital, potentially forcing financial institutions with lower levels of capital to raise fresh equity capital or sell low credit quality assets (Brunnermeier (2009), Shleifer and Vishny (2011)). The forced selling of assets into a market where the most natural buyers of the asset are themselves constrained can result in fire-sale prices (Shleifer and Vishny (1992)).

Financial institutions are required by regulators to hold a minimum level of equity capital against risky assets, a means by which regulators protect the customers of financial institutions and/or the insurance funds that insure the liabilities of these financial institutions. In the U.S., life insurance and property and casualty $(\mathrm{P} \& \mathrm{C})$ insurance companies are subject to credit-sensitive capital requirements. Banks and broker dealers are also subject to credit-sensitive capital requirements for structured finance securities. ${ }^{2}$ The amount of capital an institution has to hold is a function of the riskiness of the institution's assets. As a result, costly capital requirements on credit-impaired securities can create an incentive for financial intermediaries to sell credit-impaired securities. However, the incentive to sell credit-impaired securities is substantially heightened when firms subject to capital requirements also have to adhere to fair value (often called mark-to-market) accounting practices.

Capital requirements, together with fair value accounting, may trigger the forced sale of a financial asset for the following reason. A systematic shock to the credit quality of a portion of an institution's assets, as occurred during the massive credit downgrades of residential mortgage-backed securities

\footnotetext{
${ }^{1}$ See, for instance, Bank of England (2008).

${ }^{2}$ See Erel, Nadauld, and Stulz (2012) for a discussion of the capital requirements for U.S. banks concerning structured finance securities. Outside the U.S., banks subject to Basel II have capital requirements that are sensitive to the credit risk of their assets. U.S. banks are subject to Basel I except for market risk and structured finance securities. Under Basel I, changes in bond ratings have no impact on capital requirements.
} 
(RMBS) in 2007-2008, has two important potential effects. First, losses in the value of securities may reduce an institution's capital through the impact of losses on earnings either through fair value changes for assets held for sale or through other-than-temporary impairment (OTTI) accounting rules for assets available for sale. Second, the decreased credit quality of assets increases the regulatory capital charge that must be applied to the assets if the financial institution is subject to credit-sensitive capital requirements. The increased regulatory charge has the effect of lowering the ratio of risk-adjusted assets to capital for the financial institution. If the ratio of risk-adjusted assets to equity threatens to fall below regulatory levels, institutions face one of three choices: go out of business, raise new equity, or sell risky assets and replace them with safer assets. Given that the market for raising new capital can be limited due to the very market conditions that led to the lowering of an institution's asset quality, selling risky assets can be a capital-constrained firm's only choice, especially in the presence of accounting rules that may have already forced the recognition of losses. The "sell low credit-quality assets" strategy is viable as long as fire-sale discounts do not cause the resultant capital ratio to fall relative to pre-sale levels. If, however, fair value accounting does not apply to an asset, then the recognition of the fair value loss upon the sale of the asset may make the financial institution more capital-constrained if it sells the asset than if it keeps it. ${ }^{3}$ Thus, the combination of capital requirements and fair value accounting rules creates an economic incentive for constrained institutions to sell low quality assets, even at fire-sale prices. The preceding argument gives rise to our proposed capital-requirement-OTTI-fire-sale hypothesis.

Fire sales can be defined as forced transactions which result in prices dislocated from fundamentals. While intuitive, the identification of capital requirements and/or accounting rules as causal factors in a fire sale presents an empirical challenge for at least two reasons. First, it is difficult to measure the urgency of an observed transaction (i.e., determining that the transaction is "forced"), and more importantly, whether the urgency of the sale is on account of capital requirements or due to other factors. Second, it is difficult to clearly determine a transaction price that incorporates a fire-sale discount.

\footnotetext{
${ }^{3}$ This argument is made in Boyson, Helwege, and Jindra (2011) to argue against the economic importance of fire sales.
} 
Observed transaction prices can be low, but may very well be justified by a security's fundamentals. While we control for observables using the best available data, it may be the case that unobserved fundamentals of a security influence the observed price of a transaction, creating a bias in the estimation of the true relationship between fundamentals and transaction prices.

We propose an identification strategy that exploits the unique features of our data to address these challenges. First, we focus on the securities transactions of insurance companies. Insurance companies are required to report their securities holdings, including, importantly, the transaction price for each security trade, and whether a trade was a purchase or a sale. This allows for the identification of transactions as "purchases" or "sales" from the perspective of the insurance company, a feature we exploit in determining the sale component of forced sales. Aside from being required to disclose information on securities transactions, insurance companies are subject to regulatory capital requirements. When the investment portfolio of an insurance company experiences a decline in credit quality sufficient to raise concerns about risk-based capital ratios, regulation requires action be taken to increase the quantity of capital or the credit quality of assets, or both. In the face of a shock to credit quality, insurance companies can take one of two steps to improve their situation. Firms can either raise new capital or quickly dispose of poor credit quality assets and reinvest the funds in higher credit-quality assets to increase their levels of regulatory capital. In this way, capital requirements can trigger fire sales in that they can force capitalconstrained firms to sell low quality assets into a market where potential buyers, other intermediaries, are themselves constrained.

In addressing the second challenge, the measurement of a security's fundamentals, we focus our analysis on the transactions of non-agency (subprime and alt-a) residential mortgage-backed securities (RMBS) that are held on the balance sheets of insurance companies. We use loan-level data on the mortgage collateral of RMBS to control for changes in the fundamental value of the RMBS. Our data also provides observations from multiple transactions of the same RMBS, which allows for the creation of a repeat sales sample. Estimating changes in RMBS prices over multiple transactions on the same 
RMBS allows us to control for unobservable characteristics of the RMBS that could influence the observed transaction prices.

Testing a capital-requirement-OTTI-fire-sale hypothesis presents at least one additional empirical challenge. The level of capital at an insurance company is determined by the credit quality of the assets themselves. This makes it difficult to disentangle whether an observed sale that appears to be at a discounted, fire-sale price can be uniquely attributed to the urgency arising from low levels of capital, or a decline in the credit quality of the asset itself. To disentangle the impact of capital requirements from fundamental asset quality, we focus on a variable which is correlated with an insurance company's capital that is not correlated with the fundamental quality of its RMBS portfolio. We classify insurance companies as being more likely to be capital constrained, and thus more likely to be forced to sell low credit-quality bonds, if they report negative operating cash flow in a given year. Operating cash flow essentially represents the insurance company's underwriting income. Thus, negative operating cash flows most likely occur on account of a shock to liabilities, and should not capture any financial distress that might occur on account of a decline in the value of the RMBS held by the insurance company.

Finally, we exploit one additional feature of our data for identification. P\&C insurance companies were subject to different statutory accounting rules than life insurance companies during the bulk of our sample period. P\&C firms were required to use fair value OTTI accounting while life firms were not before 2009, when the National Association of Insurance Commissioners (NAIC) revised the standard for life firms, forcing them towards OTTI accounting. The differences in accounting practices motivate a test of the capital-requirements-OTTI-fire-sale hypothesis on the transactions of P\&C firms relative to those of life firms for the years 2006-2008. The subsequent change in accounting rules for life firms leads us to explore whether the transactions of life firms take on fire-sale characteristics in 2009.

We find the following results using a sample of 5,014 repeat transactions of non-agency RMBS between the years 2006-2009. First, we find that P\&C firms are significantly more likely than life firms to sell RMBS, conditional on an observed prior purchase. The likelihood of selling RMBS is also associated with the regulatory capital position of P\&C firms. P\&C firms with below-median levels of 
regulatory capital are more likely to sell RMBS compared to P\&C firms with above-median levels of regulatory capital. Prior to the accounting rule change in 2009 , life insurance firms exhibit no significant relationship between regulatory capital levels and propensity to sell RMBS. Our second key result is that, after controlling for observed and unobserved bond fundamentals (by virtue of the repeat sales sample), the sales of negative operating cash flow insurance companies (our instrument for capital distress in the pricing analysis) are associated with price discounts relative to the sales of positive-operating cash flow insurance companies. For P\&C firms, a one standard deviation decline in operating cash flow, conditional on the operating cash flow being negative, is associated with an estimated 8\%-12\% lower sale price, depending on the specification.

Our last result distinguishes a fire-sale hypothesis from other possible explanations of the observed empirical patterns. RMBS which have experienced large credit quality declines require more capital to be held. As such, a capital-requirements-OTTI-fire-sale hypothesis would suggest the greatest urgency, and thus the largest price discounts, to be associated with the sale of the lowest credit-quality RMBS. We provide evidence consistent with this prediction. The sales of constrained insurance companies reveal larger price discounts for bonds that have experienced the largest declines in credit-quality.

This paper is closely related to two recent papers also investigating capital requirements and fire sales. Ellul, Jotikasthira, and Lundblad (2011) document forced sales of corporate bonds by insurance companies because of the downgrading of bonds to non-investment grade ratings between 2001 and 2005. They show that such forced sales have an adverse transitory impact when made by firms that have weaker capital positions. A second paper by Ellul, Jotikasthira, Lundblad, and Wang (2012) investigates the differences between the accounting practices of $\mathrm{P} \& \mathrm{C}$ firms relative to life insurance companies. The authors document that fair value accounting motivates higher rates of selling of asset-backed securities among P\&C firms, whereas historical cost accounting for life insurance firms (hereafter called 'life firms') motivates them to hold downgraded asset-backed securities, selling corporate bonds instead. The "gains trading" of corporate bonds can induce fire sales in the corporate bond market. While similar in motivation to these papers, our evidence focuses directly on whether capital requirements and accounting 
rules led to fire sales of non-agency RMBS, the value of which played a critical role in the recent financial crisis. Our work also uses a substantially different empirical strategy in identifying the effects of capital requirements and accounting rules on fire sales. One key difference in empirical strategies is our focus on the specific transaction prices of individual securities.

Other related papers examining the investment behavior of insurance companies include Ambrose, Cai, and Helwege (2011) and Becker and Ivashina (2012). Ambrose et. al. (2011) examine regulatoryinduced trades of insurance companies and conclude that a widespread selling of bonds does not necessarily lead to pressure on prices. Rather, observed pricing declines occur on account of information effects. Becker and Ivashina (2012) show that capital requirements provide incentives for insurance companies to "reach for yield" in their security selection.

A separate stream of literature proposes collateralized lending as having contributed to fire sales in the market for real assets and financial securities. Brunnermeier and Pedersen (2009) demonstrate theoretically that a decline in funding liquidity makes arbitrageurs unable to play their role in driving mispriced assets back to their fundamental values. Mitchell and Pulvino (2012) provide empirical evidence of this mechanism at play. Unable to finance their positions during the 2008 financial crisis, hedge funds were precluded from performing their traditional role of taking advantage of mispricing through relative value trades.

Finally, our paper contributes to a growing literature focused on the costs and benefits of fair value accounting and of how fair value accounting contributed to the crisis. An early theoretical paper in this literature, by Plantin, Sapra, and Shin (2008), shows how fair value accounting can lead to a vicious cycle of sales for levered institutions. Laux and Leuz (2009) and Laux (2012) review much of the literature on the topic. Laux (2012) concludes that "there is still no evidence that fair value accounting caused widespread fire sales of assets or contagion." Some papers (e.g., Shaffer (2010)) focus on the link between fair value and bank regulatory capital. However, these papers are more concerned about the impact of fair value losses on bank capital rather than about how capital-constrained banks are pushed into fire sales. Baderscher et al. (2012) provide evidence of OTTI charges for the largest bank holding 
companies and show that, for 2007-2008, the bulk of these charges were incurred in the last two quarters of 2008. They also show that sales of RMBS are correlated with OTTI charges, but Laux (2012) argues that such a correlation can have multiple causes. One paper, Boyson, Helwege, and Jindra (2012) argues that, on net, banks did not engage in fire sales. However, in contrast to our analysis, the paper does not have transactions for individual securities. The paper correctly points out that banks had many other ways to relax capital constraints besides engaging in fire sales.

The paper proceeds as follows. In Section 1, we develop our hypotheses further and review the related literature in more detail. In Section 2, we present our data. In Section 3, we estimate the propensity to sell RMBS in our sample and show how it relates to a firm's capital position and accounting regime. In Section 4, we investigate our fire-sale predictions. We conclude in Section 5.

\section{Section 1: Hypothesis development and review of the literature}

\section{Section 1.1 Theories of Fire Sales}

Theories of fire sales describe the conditions under which forced sales occur and commonly contain two important elements: the mechanism(s) by which a forced sale is triggered and the mechanism(s) which leads to a dislocation in prices. To date, the literature has argued that leverage in general and more specifically collateralized lending can lead to the forced sale of assets (Shleifer and Vishny $(1992,1997)$ ). When debt is collateralized by a physical asset and the asset fails to generate the expected cash flows, the optimal contract calls for the sale of the asset. ${ }^{4}$ Consistent with this theory, empirical papers have documented the forced sale of collateralized, physical assets. For example, Pulvino (1998) documents that distressed airlines sold airplanes at substantially discounted prices. Collateralized lending also plays a substantial role in the forced sale of financial assets (see Brunnermeier and Pedersen (2009)). As the value of an asset financed through collateralized lending falls, margin calls force the borrower to provide more equity or to sell some of the holdings of the asset. Throughout the crisis, margin requirements

\footnotetext{
${ }^{4}$ This will be the case when the debt contract is a combination of short-term and long-term debt, with the long-term debt creating a debt overhang.
} 
increased (see Gorton and Metrick (2012)), forcing borrowers to sell assets to meet margin requirements or provide more equity. As shown by Coval and Stafford (2007), forced sales of assets can also occur when investors in an investment vehicle redeem their holdings. In sum, both theoretical and empirical work has carefully documented the mechanisms which can trigger a forced sale, the most common of which is collateralized lending.

The existence of a forced sale itself need not, however, result in dislocated prices. In wellfunctioning, liquid markets, physical or financial assets should sell at prices which reflect their best use. However, in periods of distress for the most natural purchasers of a class of assets, fire-sale prices can occur because the assets have to be bought by investors who are not natural purchasers of these assets (Shleifer and Vishny (1993)). For instance, these investors may lack the knowledge of these assets that natural buyers would have or may find the payoffs of these assets riskier within their portfolios than natural buyers would. In the case of physical assets, the most natural buyers of an asset might be defined as industry specialists. Industry specialists operate in the same industry as the asset-selling institution and are thus in a position to adequately value and utilize the asset being offered. Industry specialists can put the asset to its first-best use, and pay prices accordingly. However, if potential buyers who are industry specialists are constrained on account of financial distress, then the first-best use of the asset is not an option. Eventual purchasers of the asset will pay prices below those reflecting the asset's first-best use. Liquidity concerns can also lead to fire sales as the urgent need for liquidity can force the distressed firm to sell the asset at a discount. ${ }^{5}$ In the case of financial assets, traditional models in finance rely on arbitrageurs to keep asset prices closely aligned with fundamentals. Thus, when arbitrageurs themselves become constrained, rendering them unable to correct mispricing, prices can become more dislocated from fundamentals. ${ }^{6}$ Typically, arbitrageurs use collateralized lending. As this lending becomes harder to obtain, they become less able to provide liquidity and correct mispricing. During the crisis, as discussed

\footnotetext{
${ }^{5}$ See Benmelech and Bergman (2009) for empirical evidence regarding the role of distress in fire sales of physical assets.

${ }^{6}$ See Shleifer and Vishny (2007) for a theoretical discussion of this point and Mitchell, Pederson, and Pulvino (2007) and Mitchell and Pulvino (2010) for empirical evidence of this phenomenon.
} 
earlier, collateralized lending became harder to obtain and many securities that were initially considered to be low risk became much riskier as the crisis evolved.

The central hypothesis of this paper is that credit-sensitive capital requirements, aside from collateralized lending, can also trigger forced sales. Under this hypothesis, forced sales occur as financial institutions seek to alleviate low levels of regulatory capital through the sale of low credit quality assets. Natural buyers of the downgraded securities, many of which are themselves financial institutions, face similar regulatory capital constraints. Given the urgent need for capital, sellers rationally accept liquidity discounts on securities given that the benefit of an improved regulatory capital position outweighs the cost associated with the liquidity discount. Pricing discounts are also driven by the fact that buyers of downgraded securities find them to be positive NPV investments, but only at a sufficiently low price.

\section{Section 1.2 Other-Than-Temporary Impairment Accounting}

If assets are not valued on the balance sheet at fair value and if fair value losses have not passed through earnings, selling assets that have lost considerable value is extremely costly for a financial institution in terms of regulatory capital as the loss realized upon the sale relative to the value at which the asset is on the balance sheet goes through earnings and comes as a deduction of regulatory capital. Insurance companies held their assets on the balance sheet at amortized cost. However, under some circumstances assets held at amortized cost must be marked down to fair value when they suffer from a OTTI and the loss has to pass through earnings. With OTTI accounting treatment, a financial institution does not postpone the realization of losses by postponing the sale of an asset that has suffered fair value losses of a nature requiring OTTI treatment. Having recognized the fair value loss, the sale decision of the financial institution simply depends on the comparison of the increased capital cost of continuing to hold the security with the possible fire sale premium cost of selling the security. Absent the OTTI treatment, the increased capital cost associated with a downgraded RMBS would have to be high enough to offset the capital loss from a sale in order for there to be an incentive to sell the asset. 
During the crisis, fair value accounting rules were relaxed and the evidence is that the stock market reacted favorably to that relaxation (see Laux (2012)). However, in the insurance industry, there was also a change towards broadening the implementation of fair value accounting rules. This change creates another opportunity to identify the factors influencing RMBS sales by insurance companies. Prior to 2009, P\&C companies were required to use fair value accounting for downgraded RMBS. In contrast, life companies were allowed to use historical cost accounting for downgraded RMBS and were only required to use mark-to-market accounting for defaulted securities. However, effective in 2009, the National Association of Insurance Commissioners (NAIC) modified SSAP 43 and issued SSAP 43R requiring OTTI treatment of asset-backed securities for all insurance companies. Thus, we would expect the difference in accounting rules to manifest itself in the observed selling behavior of the two types of firms before 2009. However, during 2009, we expect both life and $\mathrm{P} \& \mathrm{C}$ insurance companies to behave consistently with a capital-requirements-OTTI-fire-sale hypothesis.

\section{Section 1.3 Capital Requirements for Insurance Companies: A Numerical Example}

Capital regulations for insurance companies are based on a system of risk-based capital calculations where total adjusted capital is calculated and compared to an authorized control level risk-based capital to determine adequacy. If the ratio of total adjusted capital to authorized control level risk-based capital falls below two, regulatory intervention is required. Comparisons between banking, securities firms, and insurance capital adequacy calculations are provided by Herring and Schuermann (2005). We focus on capital requirements for insurance companies in this paper. A detailed numerical example can help to illustrate the capital requirements and accounting mechanism at play.

In Figure 1 we provide key aspects of a hypothetical risk-based capital (RBC) calculation for an insurance company. There are four categories of risks that are explicitly considered. We focus on asset risk in this study. Each asset held by the company is categorized into six NAIC classes that correspond to various financial strength ratings. The asset value is scaled by a risk weighting, called a RBC Net Factor, to calculate risk-based capital. Lower asset quality is associated with a higher RBC Net Factor and, thus, 
higher risk-based capital. Higher risk-based capital leads to a higher company action level and a corresponding increase in total adjusted capital that must be held. Consider an insurance company that is close to the mandatory action level capital threshold with an $\mathrm{RBC}$ ratio just above two. A portion of the bond portfolio is downgraded from AAA to CCC, throwing the firm below the required level of regulatory capital where the regulator would be required to assume control of the firm. The example concludes with a demonstration of how selling the CCC-rated assets, even at fire sales prices, can restore the firm to acceptable regulatory capital levels.

The details of the example are as follows. The first step in calculating risk-based capital is to multiply the face value of a bond by the "RBC net factor," which is the risk-adjustment factor applied to a bond's face value, where the risk adjustment factor is a function of the bond's credit rating. Bonds rated AAA, $\mathrm{AA}$, and $\mathrm{A}$ are charged a net factor of 0.004 . Bonds rated $\mathrm{BBB}$ are assigned a net factor of 0.013 , BBrated bonds are charged 0.046, B-rated bonds 0.10, CCC-rated bonds 0.23 , and bonds at or near default are assigned a net factor of 0.30. Aside from credit risk-based factors, bonds are also subject to a "size factor," which we hold constant at 1.7 across all bonds in this example.

The relation between capital charges and credit quality lies at the heart of a capital requirementsOTTI-fire-sale hypothesis. As detailed in Figure 1, we consider a hypothetical portfolio with \$100M in bonds rated AAA, AA, or A, and $\$ 20 \mathrm{M}$ in bonds rated BBB. The total risk-based capital for the bonds held by the firm is $\$ 1,122 \mathrm{M}$, calculated as $\left(\left(\$ 100 \mathrm{M}^{*} 0.004\right)+\left(\$ 20 \mathrm{M}^{*} 0.013\right)\right) * 1.7$. Other risk factors (total asset risk, insurance risk, interest risk, and business risk) are then added in to arrive at a company action-level risk-based capital number of $\$ 2.464 \mathrm{M}$. Risk-based capital is then scaled by total adjusted capital which is a function of surplus (a.k.a. equity) and other nominal line items. In our example, total adjusted capital is equal to $\$ 5.6 \mathrm{M}$. Thus, the initial regulatory risk-based-capital ratio is equal to 2.272 $(\$ 5.6 \mathrm{M} / \$ 2.464 \mathrm{M})$, above the regulatory threshold of 2 .

Holding every other aspect of the regulatory capital calculation constant, we next consider the effect of a downgrade of $\$ 1 \mathrm{M}$ worth of AAA-rated bonds to a CCC-rating, and assume that the market for CCCrated bonds is at 60 cents on the dollar. The downgrade and OTTI accounting create two important 
effects. First, the insurance company must mark the face value of the bond from $\$ 1 \mathrm{M}$ to $\$ 600 \mathrm{~K}$. Second, it must recognize the $\$ 400 \mathrm{~K}$ loss on its capital, reducing the surplus from $\$ 5.5 \mathrm{M}$ to $\$ 5.1 \mathrm{M}$. The net risk factor charge on a CCC-rated bond is equal to 0.23 , making the risk-based capital charge on the downgraded bond equal to $\$ 138 \mathrm{~K}(\$ 600 \mathrm{~K} * 0.23)$. Holding everything else constant, the increased risk charge results in a company action level $\mathrm{RBC}$ amount of $\$ 2.62 \mathrm{M}$, a $\$ 227 \mathrm{~K}$ increase from the original regulatory capital level of $\$ 2.46 \mathrm{M}$. The higher risk-based capital amount, in tandem with a lower level of capital surplus on account of the forced recognition of the loss (OTTI accounting), renders a new regulatory risk-based capital ratio of 1.931 , below the regulatory threshold of 2 .

Consider the following possible response from the firm. Selling the $\$ 600 \mathrm{~K}$ of CCC-rated bonds at a fire sale price of $\$ 500 \mathrm{~K}$ would allow the firm to reinvest $\$ 500 \mathrm{~K}$ into AAA-rated securities. Doing so would force the firm to recognize the additional loss of $\$ 100 \mathrm{~K}$, leaving surplus at $\$ 5.0 \mathrm{M}$. Applying the lower risk factor charge to the new level of $\$ 99.5 \mathrm{M}$ in AAA securities, holding everything else constant, results in a company action level RBC amount of $\$ 2.461 \mathrm{M}$. When compared against the total adjusted capital amount of $\$ 5.1 \mathrm{M}$, the resultant regulatory capital ratio is restored to 2.072 , just above the regulatory threshold.

The preceding numerical example was constructed as a stylized example designed to illustrate the interaction of regulatory capital charges and asset quality. The key insights from the example are (1) OTTI accounting forces the recognition of loss when security values decline and (2) capital charges increase sharply as asset quality falls below investment grade. For an insurance company, the capital charge on a CCC-rated bond is over fifty times greater than the capital charge on a AAA-rated bond. As a result, firms in capital distress can experience a net capital gain from selling low credit quality assets, even at fire sale prices. The example is most relevant for $\mathrm{P} \& \mathrm{C}$ firms over the span of our sample and life insurance companies beginning in 2009. 


\section{Section 1.4 Fire Sale Hypotheses}

Existing theories of fire sales, in combination with the mechanics of capital requirements and OTTI accounting practices, give rise to the following four hypotheses. First, we should observe a dearth of liquidity in the market for credit-impaired securities. A lack of liquidity is ultimately what leads to pricing discounts being accepted by motivated sellers. Second, all else equal, capital-constrained P\&C firms are more likely than life insurance companies to sell downgraded securities in an illiquid market. Third, the RMBS sales of constrained firms that do occur in an illiquid market should occur at a discount in price relative to the RMBS sales of non-constrained firms. This occurs because capital-constrained sellers forced to recognize losses should be more likely to accept a liquidity discount than otherwise comparable transactions. This result should be concentrated in P\&C firms over our full sample period and in life firms during 2009. Finally, fire-sale discounts should be most severe for the most credit-impaired securities. Differentiating the magnitude of fire sale discounts as a function of credit quality uniquely identifies the role of capital requirements in the fire sale, as opposed to alternative explanations of observed discounts in prices.

\section{Section 2: Data}

\section{Section 2.1 Sample Construction}

Our sample construction begins with the universe of publicly available non-agency RMBS transactions of insurance companies. Thomson Reuters EMaxx services compiles all of the publicly reported transactions of $\mathrm{P} \& \mathrm{C}$ and life insurance companies from regulatory filings and produces a standardized bond transaction file. Data fields include transaction date, transaction price, bond CUSIP, whether the transaction was a purchase or sale, the name of the insurance company involved in the transaction, the transaction broker, transaction volume (more than one investor can own a portion of the bond), and the bond credit rating at the time of the transaction. The sample includes bonds with at least two transactions, where the second transaction occurred between January 2006 and September 2009. 
We match the universe of insurance company RMBS transactions to a database of mortgage collateral attributes produced by CoreLogic. A non-agency RMBS is collateralized by over 5,000 individual nonagency loans, on average. ${ }^{7}$ Loan-level attribute data are rolled up to the deal level using loan sizes as weights. Thus, when controlling for deal-level FICO scores, the deal-level measure represents the loanweighted FICO score of the 5,000 underlying mortgages. Importantly, our collateral attribute data is dynamic, allowing for the real-time measurement of the mortgage attributes at the time of each transaction, including the cumulative default rate on the pool of mortgages at the time of the transaction. Other real-time collateral attributes aggregated to the deal level include mortgage rates, FICOs, and combined loan-to-value ratios (LTVs). We also calculate the percentage of collateral with adjustable rates (ARMs), mortgages supporting owner-occupied homes, no or low documentation loans, and the percent that represent refinancing mortgages. We control for deal-level rates of cumulative house price appreciation by matching ZIP-code level house price indexes to the ZIP code of each mortgage. ${ }^{8}$

In dealing with a host of additional unobserved features of each RMBS (e.g., seniority in the capital structure of a deal, performance triggers, differences in pre-payment treatment, and other unobserved contractual features), we limit the sample to repeat-sales transactions of the same RMBS and estimate changes in RMBS prices from the first transaction to the second. A repeat-sale sample has the virtue of implicitly controlling for unobserved features that could impact the price of a RMBS.

Our sample period is dictated by the insurance company data availability because we require data from the income statement, balance sheet, and regulatory capital filings for each insurance company in the sample. AM Best, a firm which specializes in the production of insurance company analytics, provides income statement and balance sheet data, including data on annual levels of operating cash flow from 2006 through 2009. The National Association of Insurance Commissioners (NAIC) provides data on regulatory capital filings.

\footnotetext{
${ }^{7}$ It is important to note that the typical securitization deal produces 17 unique bonds on average. Individual mortgages do not provide cash flows for individual bonds. Rather, the entire mortgage pool generates monthly principal and interest payments which provide interest payments to bond holders. Bond coupon payments are generated from the mortgage collateral pool according to pre-specified, prioritized cash flow rules.

${ }^{8}$ We use MSA- and state-level indexes when ZIP-code indexes are unavailable.
} 
The matching of insurance company data from AM Best and the NAIC to the bond transaction and attribute data results in a sample of 10,388 unique transactions. We winsorize observations on RMBS prices and the operating cash flow of insurance companies at the $1 \%$ and $99 \%$ levels to reduce the influence of outliers in the data. Implementing a repeat-transaction criterion reduces our final sample to 5,014 repeat transactions from 385 unique life and $\mathrm{P} \& \mathrm{C}$ insurance companies over the period January 2006 toSeptember 2009.

\section{Section 2.2 Control Variables}

Our empirical tests control for fundamental attributes of RMBS which should impact RMBS prices. One of the primary determinants of RMBS performance is the default rate on the underlying pool of mortgages. Our data allow for the calculation of real-time collateral default rates. We focus on the reported collateral default rate in the month prior to the observed transaction so as to ensure that the default rate used in our estimation reflects the collateral default rate observed by market participants at the time of a transaction.

An issue that deserves special consideration is our choice to control directly for the collateral default rate as opposed to bond credit ratings, especially given that capital requirements are tied to credit ratings. The reasons for our approach are straightforward. First, insurance companies are concerned about what the rating will be at the time they compute their required regulatory capital, which occurs at the end of the calendar year. ${ }^{9}$ We believe that our approach, because of its greater timeliness, offers a better forecast of ratings for insurance companies. Second, our approach allows for greater granularity in assessing the credit quality than credit ratings allow for because we use continuous variables. Third, we are able to update our estimates of credit quality monthly using the most up-to-date information. It is commonly known that ratings are not designed to reflect real-time assessments as rating agencies are also concerned about the stability of ratings. Further, rating agencies face practical limitations in updating ratings as they have tens of thousands of ratings outstanding on structured finance.

\footnotetext{
${ }^{9}$ This argument has been highlighted in conversations with three separate industry professionals.
} 
Two pieces of data show that these considerations are important. First, during our sample period, Moody's and S\&P ratings differ, often markedly, for some deals. Such material differences could easily arise because of differences in the timing of rating updates. Second, there is considerable variation in prices within rating buckets during our sample period, which again is consistent with ratings being more up-to-date for some deals than others. Because of these considerations, we believe that our approach provides a more detailed and up-to-date assessment of credit quality than using credit ratings. We repeat our primary tests using credit ratings. While the results using credit ratings are qualitatively similar to our baseline results, they are not as robust.

Bond prices are also mechanically influenced by interest rates. Over $80 \%$ of the RMBS in our sample pay a floating coupon rate, making their value immune to direct changes in interest rates. For the small set of bonds with fixed coupon rates we control for changes in the 5-year Treasury bond rate between the first and second transactions. ${ }^{10}$ Our results are robust to the exclusion of fixed-coupon RMBS, but we include them in our reported tables so as to maximize our sample size. Other control variables that we include in the regressions are variables commonly used to predict future loan defaults. ${ }^{11}$

\section{Section 2.3 Summary Statistics}

Table 1 reports summary statistics on the quarterly attributes of our estimation sample. Each observation in the sample represents the attributes associated with the second transaction in a given repeat-transaction pair. Over the full sample period the average bond experienced a $6.9 \%$ decline in price from the first transaction to the second. The declines are concentrated primarily in 2008 , peaking in the fourth quarter, where the average bond, conditional on an observed transaction, was bought or sold for a price $41.4 \%$ less than the price of the previous transaction. The variance in price changes was also substantially larger in 2008 and 2009 than in previous years. The pattern of price declines documented in

\footnotetext{
${ }^{10}$ The expected duration of senior RMBS in our sample is about 5 years, on average.

${ }^{11}$ The impact of specific loan attributes on loan default rates is documented by Sherlund (2008), Deng, Quigley, and Van Order (2000), and Pennington-Cross and Ho (2006). Loans with high FICO scores, low loan-to-value ratios, and low debt-to-income ratios default less frequently.
} 
the initial columns of Table 1 can be observed visually in Figure 2, which plots the level of non-agency RMBS prices through time. The figure provides stunning visual evidence of the rapid decline in the market value of RMBS during the financial crisis. The rapid price declines were concentrated in RMBS that were highly rated at origination. Though not reported in Table 1, 93.3\% of the rated RMBS in our repeat sample estimation were rated AAA, AA, or A at the time of the first observed transaction.

In the full sample, $51.5 \%$ of all transactions were sales, with many fewer sales during the 2008 market crisis. One-third (33.3\%) of all life insurance transactions were associated with firms experiencing negative operating cash flows in the year of the transaction. A lower percentage of $\mathrm{P} \& \mathrm{C}$ trades (15.7\%) were associated with firms experiencing negative operating cash flows in the year of the trade. The distribution of negative operating cash flow transactions through time is lumpy. Transactions in 2007 and 2009 were more frequently associated with negative operating cash flow insurance firms compared to transactions in 2006 and 2008. As expected, default rates on mortgage collateral at the time of the transaction were highest during the years 2008 and 2009, periods which represented the largest declines in bond value. This fact highlights the need for careful identification of the unique impact of capital requirements, as opposed to RMBS fundamentals, in explaining the observed low prices paid for RMBS. Observed RMBS prices were low in 2008 and 2009, but so was the quality of their fundamentals.

\section{Section 3: Estimating the Propensity to Sell RMBS.}

Section 3.1. Liquidity in the non-agency RMBS market.

A central feature of theories of fire sales is a lack of liquidity in the market for the asset. In this section we document liquidity in the non-agency RMBS market amongst insurance companies between the years 2006-September 2009. The available data is not suitable to estimate the liquidity measures that are commonly used in the literature. These measures require bid-ask prices, trade data, or volume data. Here, we can only show the extent to which insurance companies made RMBS purchases and sales. We find that our proxy for liquidity, the number of purchases and sales, dropped sharply during the crisis. 
In Figure 3 we provide a plot of the three-month moving average of the total number of $\mathrm{P} \& \mathrm{C}$ and life RMBS transactions. The market appeared most liquid in June 2006 where the three-month moving average of unique trades within our sample topped 300 trades per month. Liquidity in the market remained fairly steady from this point until taking a dramatic dive at the beginning of 2008. Liquidity fell throughout the next nine months hitting a low in the summer of 2008 when the market transacted nearly 85 trades per month, on average.

The lack of liquidity was most highly concentrated in sales transactions. In Figure 4 we plot the number of purchases and sales separately. The majority of transactions per month during the summer of 2008 consisted of purchases. Sales averaged less than 20 transactions per month during the summer of 2008. The evidence provided in Figures 3 and 4 is consistent with a lack of liquidity in the market for non-agency RMBS, a condition which could result in securities being transacted at fire sales.

\section{Section 3.2. Are constrained firms more likely to sell?}

Evidence presented in Section 3.1 indicates that the market for RMBS had many fewer transactions during the financial crisis, which we interpret as evidence of the lack of liquidity required for fire-sale discounts to occur. In this section, we test a second condition of the fire sales hypothesis, namely, whether capital-constrained firms are more likely to sell securities. Under a capital-requirement-OTTIfire-sale hypothesis, the urgency of obtaining the capital relief that comes with selling a marked-tomarket, low-credit-quality asset outweighs the cost of the expected fire sale discount. As such, we expect that capital-constrained firms subject to OTTI accounting will be more likely to sell, all else equal.

To test this aspect of a capital-requirement-OTTI-fire-sale hypothesis we estimate a Cox proportional hazard model using a firm-RMBS panel data set. For each unique RMBS purchase observed between 2006-2008, we construct a panel of monthly observations on the attributes of the mortgage collateral supporting the purchased RMBS as well as the attributes of the insurance company which purchased the RMBS. We track the attributes of the RMBS beginning at the date of purchase through time until either we observe the selling of the RMBS by the original purchasing firm or our sample period ends. We begin 
the panel in 2006 because it is the first year for which we have insurance company data. We end the sample in 2008 so as to preserve the key difference between P\&C and life firms' adherence to mark-tomarket accounting in our estimates.

In the proportional hazard estimation, "failure" is the sale of an RMBS while the retention of a purchased RMBS through the full sample period represents "survival." The conditional nature of the proportional hazard estimation allows us to control for the attributes of RMBS collateral which influence the selling decision through time. Our baseline specification controls for several key measures of the attributes of the RMBS collateral during each month the bond is held in the portfolio. These include the RMBS collateral default rate in the month prior to the transaction as well as the cumulative rate of ZIP code-level house price appreciation for the mortgage pool since origination. We also control for poollevel FICO, combined LTV, the percentage of mortgages that are ARMs, owner occupied, no/low documentation, or refinancing mortgages. We cluster standard errors by month.

Table 2 reports results of the hazard estimation. Column (1) includes both life and $\mathrm{P} \& \mathrm{C}$ firms in the estimation. We create a $\mathrm{P} \& \mathrm{C}$ indicator variable designed to measure the difference between life and $\mathrm{P} \& \mathrm{C}$ firms in the propensity to sell, conditional on the real-time attributes of the RMBS. The estimated coefficient on the $\mathrm{P} \& \mathrm{C}$ indicator is positive and statistically significant, indicating that for a given set of RMBS characteristics - including time held in portfolio - P\&C firms are more likely to sell RMBS. In terms of economic significance, the magnitude of the estimated coefficient indicates that at sampleaverage collateral values, RMBS are predicted to remain in $\mathrm{P} \& \mathrm{C}$ portfolios 5 months less than in life portfolios, all else equal.

The results in Column (1) are consistent with the prediction that $\mathrm{P} \& \mathrm{C}$ firms are more likely to sell RMBS, but the estimation in Column (1) does not clearly identify the role of capital requirements. The difference in selling propensity driving the positive estimate on the $\mathrm{P} \& \mathrm{C}$ indicator could also be attributed to a host of unobservable differences between the two firm types. This includes the possibilities that $\mathrm{P} \& \mathrm{C}$ firms could have higher portfolio churn on account of a more frequently changing liability structure compared to life firms or because of more frequent policy redemptions. In an effort to identify the role of 
capital requirements in the selling decision more directly, we create an indicator variable for firms with below-median RBC in a given year. Under a capital-requirements-OTTI-fire-sale hypothesis, firms with low levels of RBC would feel a greater urgency to sell RMBS compared to less capital-constrained firms.

In columns (2) and (4) we split the sample by insurance type and estimate the proportional hazard model where the below-median $\mathrm{RBC}$ indicator is the independent variable of interest. The results in Column (2) suggest that below-median RBC P\&C firms are significantly more likely to sell than abovemedian P\&C firms, conditional on a given set of RMBS characteristics. Holding RMBS attributes at the P\&C sample average, below-median P\&C firms were predicted to hold RMBS 6 fewer months than above-median $\mathrm{P} \& \mathrm{C}$ firms. In contrast, the results in Column (4) indicate that the RBC position of life firms has no significant impact on their propensity to sell.

In Columns (3) and (5) we test whether the propensity for below-median RBC firms to sell is different at a given level of collateral default. A capital-requirement-OTTI-fire-sale hypothesis predicts that the urgency of selling would be higher for poor credit-quality RMBS held by low capital firms subject to OTTI accounting practices. In testing the poor credit-quality aspect of this prediction we create a new variable which measures the interaction of the real-time mortgage collateral default rate with the below-median RBC indicator for the P\&C and life samples, respectively. Though the previous estimates control for the average level of real-time credit attributes of the RMBS, the interaction term measures the propensity to sell at a given level of collateral default. For the P\&C sample, as reported in Column (3), the estimated coefficient on the key interaction term is not statistically different from zero. In the life sample, as reported in Column (5), the estimate on the key interaction term is also insignificant.

The results from the Cox proportional hazard estimation support two of the key predictions of a capital-requirement-OTTI-fire-sale hypothesis. First, P\&C firms are significantly more likely to sell RMBS than life firms. Second, the likelihood of selling is correlated with the RBC position of P\&C firms but not with the RBC position of life firms. 


\section{Section 4: Estimating Fire-Sale Effects in RMBS.}

\section{Section 4.1 Do capital constrained firms sell bonds at lower prices?}

While a probability-based estimation strategy has the potential to estimate the likelihood of observing sales, probability-based estimates are not as effective at capturing the urgency to sell. Tests involving market prices are better suited for the estimation of liquidity discounts on account of selling urgency. In this section we document pricing patterns that exist in the data and evaluate whether the observed patterns are consistent with the fire sales hypothesis.

Our primary hypothesis states that the combination of capital requirements and accounting rules should influence the observed transaction prices of RMBS. The effect should be pronounced in P\&C firms on account of their adherence to mark-to-market accounting practices. As a first pass approach in evaluating the relationship between a firm's RBC and the price of RMBS transactions we calculate the $\mathrm{RBC}$ ratio for each $\mathrm{P} \& \mathrm{C}$ firm in our sample and stratify trades into above- and below-median RBC buckets. ${ }^{12}$ Table 3 presents P\&C summary statistics on the average price change between the first and second RMBS transactions of the same bond in a matched transaction pair. Columns (1) and (2) of Panel A document that, on average, below-median $\mathrm{RBC} P \& \mathrm{C}$ firms are associated with transactions which declined $8.0 \%$ in price compared to average $6.2 \%$ declines for above-median RBC firms.

Such a discrepancy could be attributed to more frequent sales for below-median RBC firms given the potentially large bid-ask spreads in an illiquid market. In order to adjust for the difference between sales and purchases, Columns (3) and (4) of Panel A document differences between the price changes of aboveand below-median RBC P\&C firms using a sample of only sales transactions. In the sales-only sample, above-median RBC firms experienced average price declines of $4.7 \%$ compared to an average price decline of $7.5 \%$ for below-median RBC firms.

Panel A adjusts for differences in purchases and sales transactions, but does not adjust for differences in collateral credit quality. Columns (5) and (6) of Panel B document differences in price changes for

\footnotetext{
${ }^{12}$ Above- and below-median RBC calculations are performed in each year of the sample for P\&C and life firms separately.
} 
above and below-median RBC firms in a sales-only sample on transactions with above-median collateral default rates. Above-median RBC P\&C firms selling RMBS with above-median default rates exhibit average price declines of $4.7 \%$ compared to $13.6 \%$ price declines for below-median RBC firms selling RMBS with above-median default rates. By contrast, in a sales-only sample of transactions with belowmedian collateral default rates, as documented in Columns (7) and (8), the price changes between aboveand below-median RBC firms only differ by a few percentage points. Consistent with a capitalrequirement-OTTI-fire-sale hypothesis, the summary statistics presented in Table 3 clearly indicate that OTTI-adhering P\&C firms that are regulatory-capital constrained sell low credit quality RMBS at a discount compared to non-regulatory capital constrained P\&C firms.

In Table 4 we reproduce the results of Table 3 on a sample of repeat-RMBS transactions for life insurance companies. Given that life insurance companies were not required to adhere to fair value accounting practices prior to 2009 we would not expect to observe similar sensitivity of pricing to regulatory-capital positions and collateral default rates as exhibited by $\mathrm{P} \& \mathrm{C}$ firms in Table 3 . Columns (1) and (2) document that, on average, above-median RBC life insurance companies are associated with larger pricing declines than below-median RBC firms, a result opposite to that ofr P\&C firms. Such a result is fully consistent with the view that accrual accounting delays sales of securities that have made losses for companies with weaker capital positions. A similar pattern holds when examining the salesonly sample as tabulated in Columns (3) and (4). Columns (5) and (6) reveal that pricing declines are higher still for above-median RBC firms transacting in RMBS with above-median collateral default rates. This result suggests that life insurance companies are sensitive to the credit quality of RMBS, but that the sensitivity is not related to their capital position, at least prior to 2009 , as would be predicted under a capital-requirement-OTTI-fire-sale hypothesis.

Section 4.2 Do lower levels of capital cause fire sales?

Broadly speaking, the simple univariate comparisons provided in Table 3 show that poorly capitalized $\mathrm{P} \& \mathrm{C}$ insurance companies consistently sold bonds at a discount relative to better capitalized insurance 
companies. This pattern does not hold for life insurance companies, at least prior to 2009. The observed pattern is potentially consistent with a capital-requirements-OTTI-fire-sale hypothesis. However, the evidence does not rule out viable alternative explanations. First, the differences do not control for unobservable attributes of the RMBS. Poorly capitalized firms may systematically own bonds of poorer credit quality, justifying the lower observed prices.

A more subtle explanation, even more at odds with a capital-requirements-OTTI-fire-sale hypothesis, is the possibility that the lower prices of the below-median RBC firms are justified by systematically lower credit quality RMBS, so that losses associated with poor credit-quality RMBS are themselves responsible for the lower levels of capital in the firm. Under this explanation, the below-median RBC firms have lower levels of capital because they own portfolios of RMBS that are of systematically lower credit quality and prices of RMBS of a systematically lower credit quality are appropriately discounted by the market.

In this section we propose a specification designed to disentangle the endogenous relationship between firm capital and RMBS credit quality in order to appropriately test a capital-requirements-OTTIfire-sales hypothesis. As a starting point, consider a simple, linear model of the following form:

$$
\text { Price }_{i, t}=\alpha+\beta \cdot \text { Constrained Firm Indicator }_{j, t}+\delta X_{i, t}+\varepsilon_{i, t} \text {, }
$$

where subscripts $i$ and $t$ represent RMBS $i$ transacted at time $t$, subscript $j$ represents firm $j$ and $X$ represents a matrix of bond fundamentals.

$X$ includes the full set of RMBS-specific fundamentals described in the data section. In addition to observable attributes of the collateral, a specification explaining variation in RMBS prices must address other issues. The repeat-transaction criterion implicitly controls for deal-specific features of each RMBS such as seniority in the deal's capital structure and other unobserved contractual features. Despite these sample criteria, omitted variables may still plague the proposed pricing specification. The most obvious concern is that an unobserved attribute of RMBS quality could itself be the cause of an intermediary's constrained capital position. RMBS values are not exogenous to a firm's capital position because an otherwise healthy firm could suffer capital distress on account of the credit attributes of the RMBS 
portfolio itself. Such an omitted variable bias may make it difficult to determine whether a constrained seller's transaction of an RMBS at a dislocated price is on account of capital expediency or because of unobserved features of RMBS credit quality that cause the firm to sell the RMBS and that justify a dislocated price.

We propose using negative shocks to a firm's cash from operations as an instrument for the capital urgency of a firm. Cash from operations essentially represent an insurance company's underwriting income. As such, negative cash from operations represents an episode of increased liabilities, triggered most frequently by an increase in insurance claims. Negative cash from operations should not be influenced by recognizing losses on RMBS because, in the accounting treatment of insurance companies, investment income does not contribute to cash from operations. Because of this, negative cash from operations should be correlated with firms experiencing capital distress; however, the source of distress should not be correlated with the fundamentals of the RMBS we are trying to evaluate. We scale operating cash flow by the level of total capital in a given year in order to capture the contribution or destruction of capital that can be attributed to a given level of operating cash flow in that year.

As a check on the validity of negative operating cash flow shocks as an instrument for capital distress, we examine the empirical relationship between year-over-year changes in levels of capital at insurance companies and episodes of negative operating cash flows. In our sample of insurance companies, firms experiencing a negative operating cash flow shock in a given year are associated with statistically significant $9.8 \%$ lower levels of capital compared to the previous year, on average. The result is consistent across each of the years in our sample period. In contrast, the average firm in our sample not exposed to a negative cash flow shock experienced a $6.1 \%$ increase in capital each year in the sample period.

\section{Section 4.3. RMBS pricing and operating cash flow shocks}

In this section we test the pricing aspects of a capital-requirement-OTTI-fire sale hypothesis, which argues that the sales of 'adverse-shock-to-capital' firms that do occur should reflect a discount in price 
relative to the sales of non-capital shocked firms for RMBS of a similar credit quality. The prediction is based on the argument that the capital relief associated with selling a credit-impaired bond outweighs the cost associated with selling the credit-impaired bond, even if the expediency of selling the bond results in a fire-sale discount.

The use of a repeat sales sample in our estimation requires careful attention to the potential empirical issues it presents. One such challenge is the handling of bid-ask spreads, particularly in an illiquid market. Our dependent variable is calculated as the percent change in the price of an RMBS from the previous transaction to the second transaction. We create a sale indicator variable which is equal to one if the second transaction in a pair of transactions is a sale because we are interested in testing whether the sales of capital constrained firms are statistically different from the sales of non-constrained firms, all else equal. Drawing inferences on fire sales from the coefficient on the sales indicator is potentially difficult because sales are expected to be consistently lower by virtue of a bid-ask spread, particularly if the previous transaction was a purchase. We overcome this challenge through the interaction of the sale indicator with the operating-cash-flow-to-capital ratio. The interaction term allows for a comparison of sales transactions of firms with various levels of operating cash flow. It is not clear ex ante why any bidask spread bias of sale transactions would be correlated with the ratio of operating-cash-flow-to-capital of the seller in a given year. Accordingly, we expect the estimated coefficient on the sale, capitalconstrained interaction variable to represent a reasonable estimate of the difference in sales between capital constrained and less-constrained firms. ${ }^{13}$

A second issue of a repeat sales approach which deserves careful attention is the amount of time between each transaction. Though we control for quarter fixed effects, changes in market conditions in the time between two unique transactions would not be captured by simple quarter fixed effects. We control for the number of months from the prior trade as an additional factor which could impact the

\footnotetext{
${ }^{13}$ One remaining bid-ask spread issue to consider is whether the first transaction in a repeat transaction pair was a purchase or sale transaction. Purchase-sale pairs would be expected to experience larger negative price changes than an otherwise comparable purchase-purchase pair because of bid-ask spreads. While this is a concern conceptually, we confirm in the data that price changes associated with purchase-sale paired transactions are not statistically different than price changes in purchase-purchase pairs.
} 
change in price between two consecutive transactions of the same RMBS. We also interact the numberof-months-from-prior-trade variable with the quarterly time dummies, so as to capture any changing dynamics in the market that could occur in the time between two transactions.

The repeat sales sample also influences the specification of our control variables. Rather than controlling for the level of collateral attributes such as collateral default rates, rates of house price appreciation, etc., we control for changes in the control variables from the time of the first transaction to the second. The change in collateral attributes should more accurately capture the change in credit quality which might influence observed pricing changes. For example, two unique pairs of repeat transactions might be associated with the same level of collateral default rates at the time of the second transaction, but one pair of transactions might be associated with a much larger relative change in default rates between the first and second transactions. Fundamentally, we believe the change in the price between the two transactions should reflect the change in collateral attributes, not just the level of attributes at the time of the second transaction.

Finally, the relationship between price changes and the sign of operating cash flow is likely to be asymmetric. A positive operating cash position of an insurance company in a given year should have little bearing on the capital urgency of the firm and thus the urgency of selling an impaired RMBS. We would expect non-capital constrained firms to be less likely to accept the price discounts associated with a "forced" sale transaction. However, a negative operating cash flow position should be associated with an urgent sale and the potential to accept a liquidity discount to remove the capital requirement associated with an impaired security. In order to capture the potential asymmetry in our estimates, we split the estimation sample into transactions of firms with negative operating cash flow and positive operating cash flow.

Table 5 reports the estimation results of our pricing specification. The dependent variable in each specification is the change in price from the first transaction to the second. Control variables include changes in collateral attributes, changes in market interest rates, the time between the two transactions, quarterly fixed effects, and the interaction of the quarterly fixed effects with the time-between- 
transactions variable. We cluster standard errors by the second transaction month. The sample period in columns (1) and (2) is January 2006 to September 2009 given the adherence to mark-to-market accounting practices for $\mathrm{P} \& \mathrm{C}$ firms over that whole period. The coefficient of interest in Column (1) is the interaction of the operating cash-to-capital ratio with the sale indicator. The interaction term is positive, indicating that the sales of firms with larger negative operating cash flows are associated with larger price declines. The magnitude of the estimate indicates that a one-standard deviation decline in the operating cash to capital ratio, from the mean of -.27 to -.69 , results in a $8.2 \%$ price decline. In contrast, the interaction of the sale indicator with the continuous measure of positive operating cash flows, as reported in Column (2), is not significantly different from zero.

Columns (3) and (4) of Table 5 repeat the estimation for the sample of life firms using the 2006-2008 sample period in which life firms did not uniformly follow OTTI accounting practices. The key interaction term, operating-cash-to-capital*sale-transaction, is not statistically different from zero in the negative or positive operating cash flow samples. This result is consistent with a lack of selling urgency for life firms given their ability to hold RMBS on the books at historical cost. As a means of identifying the effect of OTTI accounting on the urgency of selling, in Columns (5) and (6) we estimate the same specification using a sample of repeat transactions for life firms where the second transaction occurred in 2009. Given the adoption of OTTI accounting for life firms within the year 2009, such transactions could reflect the fire sale characteristics fueled by the combination of OTTI accounting and capital requirements. The positive and significant estimate on the operating-cash-to-capital*sale-transaction interaction term indicates the fire sale mechanism at play in 2009. Life firms in 2009 that experienced larger negative operating cash flow shocks were involved in RMBS sales that occurred at significant discounts relative to the prior transaction. The estimated coefficient suggests pricing discounts as large as $12.5 \%$ for life firms experiencing a one-standard deviation more severe level of negative operating cash flow. By way of comparison, the sales of life firms with positive operating cash flow in 2009 do not demonstrate similar pricing patterns. 
The results presented in Table 5 appear consistent with a capital-requirements-OTTI-fire-sale hypothesis. All else equal, when selling an RMBS, a firm which experienced a larger negative operating cash flow shock sold RMBS at a statistically significant lower price compared to a firm with a less negative operating cash flow shock. The results only hold during periods in which firms adhere to OTTI accounting practices. However, despite the consistency of the results with a capital-requirements-OTTIfire-sale hypothesis, the results still do not rule out viable alternatives. Any issue besides capital requirements which impacts an insurance company's need for liquidity could be addressed through the forced sale of securities. For example, life insurance firms may face higher policy redemptions, forcing the firm to liquidate assets at potential fire sale prices to meet client's liquidity demands. Such a demand for liquidity would affect operating cash flow and could produce results consistent with those documented in Tables 2-5. In the following section we propose a specification designed to test a unique aspect of a capital-requirements-OTTI-fire-sale hypothesis.

Section 4.4. Does the credit quality of the bond influence the magnitude of fire sale discounts?

Regulatory capital charges increase as the credit quality of assets declines. As detailed in Section 1.2, in the case of insurance companies, assets of the highest credit-quality are assigned a 0.004 capital charge while assets of poor-quality are assigned a substantially larger 0.23 capital charge. The inverse and nonlinear relationship that exists between the credit quality of an asset and the amount of capital that must be held against the asset gives rise to our final test. Price discounts associated with urgent sales should be most severe for the most severely credit-impaired securities.

A test of this hypothesis requires objective measurement of the credit quality of RMBS. As before, we use observable default rates in the month prior to a transaction as our measure of credit quality. We calculate collateral default rates as being above or below median at the time of the second transaction for each repeat sample pair. We then create a variable which interacts the operating cash flow variable with the sale indicator and an above-median default indicator. The above-median default calculation uses the full sample of default rates as of the second transaction. The three-way interaction should measure the 
marginal pricing difference between the sales of capital constrained firms on high versus low creditquality RMBS. As was the case in Table 5, we estimate the regression separately for negative and positive operating cash flow firms.

Table 6 presents the results of this test. We control for the same set of collateral attributes as in previous tables, with the exception of default rates. The above-median default rate indicator serves as a proxy for the level of default rates in this specification. As reported in Column (1), the estimated coefficient on the operating cash*sale transaction*above-median defaults is positive and statistically significant. The positive coefficient indicates that sales from firms with larger negative shocks to operating cash flow are associated with larger negative bond price changes for high collateral default RMBS compared to low collateral default RMBS. In contrast, column (2) reports results of the estimation in the negative operating cash sample of life firms between the years 2006-2008. The estimated coefficient on the interaction of interest is not statistically significant, consistent with estimates on life transactions reported in previous tables. Column (3) reports results using the sample of life transactions in 2009. Consistent with results presented in Table 5, the results documented in Column (3) indicate that transactions of life firms exhibited fire sale characteristics in 2009 and that fire-sale discounts were largest on RMBS of the worst credit quality. The existence and magnitude of fire sale discounts appear to be related to the credit quality of the RMBS, but only for firms subject to OTTI accounting.

Taken together, we interpret our results to be consistent with a capital-requirements-OTTI-fire-sale hypothesis. If an omitted variable were driving these results, such a variable would have to be uniquely correlated with the sales of the worst credit-quality bonds of insurance companies that have experienced a negative shock to operating cash flows but not correlated with the sales of the worst credit-quality bonds of insurance companies with positive operating cash flow. The omitted variable would also have to be correlated only with $\mathrm{P} \& \mathrm{C}$ firms through the full sample period and not life firms except during the year 2009. While it is difficult to conclusively rule out all possible alternatives, we cannot identify alternative hypotheses that are consistent with the observed empirical patterns. 


\section{Section 5. Conclusion}

The role of collateralized lending is a common theme in some of the recent influential papers on the financial crisis (Brunnermeier and Pederson (2009), Shleifer and Vishny (2011)). These papers argue that the liquidation of financing positions which were collateralized by financial assets led to fire sales in financial markets. In this paper, we consider capital requirements as a second important mechanism which may contribute to fire sales in financial markets. We describe the economics of how capital requirements can lead to fire sales and show that mark-to-market accounting is a critical requirement for such fire sales to occur. We propose and test hypotheses designed to identify a capital requirement channel at play in the transactions of non-agency RMBS by insurance companies. Understanding the economics surrounding the market valuation of non-agency RMBS during the financial crisis is important given the critical role that RMBS played in destabilizing financial institutions' balance sheets. ${ }^{14}$

We show that the interplay of mark-to-market accounting rules and credit-quality based capital requirements can create an economic incentive for a capital-constrained firm to sell credit-impaired financial assets even, potentially, at fire-sale prices. In particular, even for assets available for sale, OTTI accounting rules force financial firms to mark financial assets to market prices, thereby recognizing the loss associated with a decline in an asset's credit quality. Declines in credit quality have a second important effect, which is that they raise the capital costs associated with holding a credit impaired asset on a balance sheet if the capital requirements are credit-quality sensitive. Not all financial institutions face credit-quality sensitive capital requirements, but insurance companies are among those that do. The capital costs associated with holding a credit-impaired asset may be more onerous than a firm is willing to bear. Seeking capital relief, capital constrained firms may have to quickly sell credit-impaired assets, accepting liquidity discounts associated with an urgent sale.

We provide empirical evidence consistent with the capital-requirements-OTTI-fire-sale hypothesis. We find that insurance companies subject to mark-to-market accounting practices with low levels of

\footnotetext{
${ }^{14}$ See Erel, Nadauld, and Stulz (2012) for a discussion of the importance of RMBS and other structured finance instruments on the balance sheet of financial institutions.
} 
capital are more likely to sell RMBS, all else equal. When capital-constrained insurance companies do sell RMBS, they sell RMBS at prices lower than sales of non-capital constrained insurance companies. We further document that the fire sale discounts of capital constrained firms increase as the credit quality of the asset being sold declines. This result is consistent with a regulatory system which assigns capital charges as a function of asset quality. Our analysis employs data from insurance companies but our results have broad implications for financial institutions of all types. Though calculated differently at banks than insurance companies, capital requirements can create incentives for banks to unload assets at fire sale prices. While capital requirements for U.S. banks were not credit-quality sensitive for loans, they were for structured finance securities such as RMBS, so that we would expect the issues raised in this paper to be relevant for RMBS transactions by banks as well.

We believe this work highlights a potentially unanticipated consequence of the interaction between fair value accounting and credit-sensitive capital requirements. Capital requirements can create incentives for firms to sell fair-valued assets into an illiquid market, thereby further destabilizing the market for a given asset class and further weakening the balance sheets of those firms least able to withstand such weakening. 


\section{References}

Ambrose, Brent W., Cai, Kelly Nianyun, and Jean Helwege. 2011 "Fallen Angels and Price Pressure." Working Paper.

Baderscher, Brad, Jeffrey J. Banks, and Peter D. Easton, 2012. "A Convenient Scapegoat: Fair Value Accounting by Commercial Banks during the Financial Crisis." The Accounting Review, 87(1).

Bank of England, 2008, Financial Stability Report, April.

Becker, Bo, and Victoria Ivashina. 2012. "Reaching for Yield in the Bond Market.” Working Paper.

Benmelech, Efraim, and Nittai K. Bergman. 2009. "Liquidation Values and the Credibility of Financial Contract Renegotiation: Evidence from U.S. Airlines." Quarterly Journal of Economics, 123(4): $1635-77$.

Boyson, Nicole, Helwege, Jean, and Jindra, Jan. 2012. "Crises, Liquidity Shocks, and Fire Sales at Commercial Banks.” Working paper.

Brunnermeier, M. K., 2009, Deciphering the liquidity and credit crunch 2007-2008, Journal of Economic Perspectives, 23: 77-100.

Brunnermeier, Markus, and Lasse H. Pedersen. 2009. "Market Liquidity and Funding Liquidity." Review of Financial Studies, 22(6): 2201-38.

Coval, Joshua D., and Erik Stafford. 2007. “Asset Fire Sales (and Purchases) in Equity Markets.” Journal of Financial Economics, 86(2): 479-512.

Deng, Yongheng, John M. Quigley, and Robert Van Order, 2000. "Mortgage Terminations, Heterogeneity, and the Exercise of Mortgage Options," Econometrica 68(2): 275-307.

Ellul, Andrew, Jotikasthira, Pab and Lundblad, Christian T. 2010. "Regulatory Pressure and Fire Sales in the Corporate Bond Market." Journal of Financial Economics, forthcoming.

Ellul, Andrew, Jotikasthira, Pab, Lundblad, Christian T. and Yihui Wang. 2012. "Is Historical Cost Accounting a Panacea? Market Stress, Incentive Distortions, and Gains Trading.” Working Paper.

Erel, Isil, Nadauld, Taylor, and René M. Stulz. 2012. "Why Did U.S. Banks Invest in Highly-Rated Securitization Tranches?” NBER Working Paper.

Gorton, Gary, and Andrew Metrick. 2010. "Securitized Banking and the Run on Repo." Journal of Financial Economics 104 (3), 425-451,

Herring, R., and Til Schuermann, 2005. Capital Regulation for Position Risk in Banks, Securities Firms, and Insurance Companies. In: Scott, Hal S (Ed.), Capital Adequacy Beyond Basel: Bank, Securities and Insurance. Oxford University Press, New York, chapter 1.

Laux, Christian. 2012. "Financial Instruments, Financial Reporting, and Financial Stability.” Working Paper. 
Laux, Christian, and Christian Leuz. 2009. "Did Fair-Value Accounting Contribute to the Financial Crisis?” NBER Working Paper.

Mitchell, Mark, and Todd Pulvino. 2011. “Arbitrage Crashes and the Speed of Capital.” Journal of Financial Economics 104 (3), 469-490.

Mitchell, Mark, Lasse Pedersen, and Todd Pulvino, 2007. "Slow Moving Capital.” American Economic Review 97, 215-220.

Pennington-Cross, A., Ho, G. 2006. "The Termination of Subprime Hybrid and Fixed Rate Mortgages," Working Paper, Federal Reserve Bank of St. Louis.

Plantin, Guillaume, Haresh Sapra, and Hyun Song Shin, 2008. "Marking-to-Market: Panacea or Pandora's Box?” Journal of Accounting Research, 46(2):435-460.

Pulvino, Todd. 1998. "Do Fire-Sales Exist? An Empirical Study of Commercial Aircraft Transactions." Journal of Finance, 53(3): 939-78.

Shaffer, Sanders. 2010. "Fair Value Accounting: Villain or Innocent Victim - Exploring the Links between Fair Value Accounting, Bank Regulatory Capital and the Recent Financial Crisis," FRB of Boston Quantitative Analysis Unit Working Paper.

Sherlund, Shane, 2008. "The past, present, and future of subprime mortgages." Finance and Economics Discussion Series, Federal Reserve Board.

Shleifer, Andrei, and Robert W. Vishny. 1992. "Liquidation Values and Debt Capacity: A Market Equilibrium Approach.” Journal of Finance, 47(4): 1343-66.

Shleifer, Andrei, and Robert W. Vishny. 1997. "The Limits of Arbitrage.” Journal of Finance, 52(1): 3555.

Shleifer, Andrei, and Robert Vishny. 2011. "Fire Sales in Finance and Macroeconomics" Journal of Economic Perspectives, 25(1): 29-48. 
Figure 1. A Numerical Example of Capital Requirements in the Insurance Industry.

\author{
Asset Risk \\ NAIC Class 1 Bonds (AAA, AA, A) \\ NAIC Class 2 Bonds (BBB) \\ NAIC Class 5 Bonds (CCC) \\ Bonds subject to size factor \\ Size Factor \\ Total RBC for Bonds \\ Common Stock \\ Asset Concentration Factor \\ Total Asset Risk - C1 \\ Total Insurance Risk - C2 \\ Total Interest Risk - C3 \\ Total Business Risk - C4 \\ Total Risk Based Capital \\ Effect of Covariance \\ Company Action Level RBC \\ Surplus \\ Asset Valuation Reserve \\ Dividend Liability \\ Total Adjusted Capital
}

RBC Ratio
Before MBS Downgrade

\begin{tabular}{|c|c|c|}
\hline $\begin{array}{l}\text { Statement } \\
\text { Value }\end{array}$ & $\begin{array}{l}\text { RBC net } \\
\text { Factor }\end{array}$ & $\begin{array}{l}\text { Risk-Based } \\
\text { Capital }\end{array}$ \\
\hline $100,000,000$ & 0.004 & 400,000 \\
\hline \multirow[t]{4}{*}{$20,000,000$} & 0.013 & 260,000 \\
\hline & & 660,000 \\
\hline & & 1.7 \\
\hline & & $1,122,000$ \\
\hline \multirow[t]{13}{*}{$1,000,000$} & 0.2925 & 292,500 \\
\hline & & 45,000 \\
\hline & & $1,459,500$ \\
\hline & & 874,250 \\
\hline & & 672,750 \\
\hline & & 160,160 \\
\hline & & $3,166,660$ \\
\hline & & $-701,982$ \\
\hline & & $2,464,678$ \\
\hline & & $5,500,000$ \\
\hline & & 75,000 \\
\hline & & 25,000 \\
\hline & & $5,600,000$ \\
\hline
\end{tabular}

After MBS Downgrade

\begin{tabular}{|c|c|c|}
\hline $\begin{array}{c}\text { Statement } \\
\text { Value }\end{array}$ & $\begin{array}{l}\text { RBC net } \\
\text { Factor }\end{array}$ & $\begin{array}{c}\text { Risk-Based } \\
\text { Capital }\end{array}$ \\
\hline $99,000,000$ & 0.004 & 396,000 \\
\hline $20,000,000$ & 0.013 & 260,000 \\
\hline \multirow[t]{4}{*}{600,000} & 0.23 & 138,000 \\
\hline & & 794,000 \\
\hline & & 1.7 \\
\hline & & $1,349,800$ \\
\hline \multirow[t]{13}{*}{$1,000,000$} & 0.2925 & 292,500 \\
\hline & & 45,000 \\
\hline & & $1,687,300$ \\
\hline & & 874,250 \\
\hline & & 672,750 \\
\hline & & 160,160 \\
\hline & & $3,394,460$ \\
\hline & & $-701,982$ \\
\hline & & $2,692,478$ \\
\hline & & $5,100,000$ \\
\hline & & 75,000 \\
\hline & & 25,000 \\
\hline & & $5,200,000$ \\
\hline
\end{tabular}

After Hypothetical CCC-Rated MBS Fire Sale

\begin{tabular}{rrr}
\multicolumn{1}{l}{$\begin{array}{c}\text { Statement } \\
\text { Value }\end{array}$} & \multicolumn{1}{c}{$\begin{array}{c}\text { RBC net } \\
\text { Factor }\end{array}$} & \multicolumn{1}{c}{$\begin{array}{c}\text { Risk-Based } \\
\text { Capital }\end{array}$} \\
$99,500,000$ & 0.004 & 398,000 \\
$20,000,000$ & 0.013 & 260,000 \\
0 & 0.23 & 0 \\
& & 658,000 \\
& & 1.7 \\
& & $1,118,600$ \\
$1,000,000$ & 0.2925 & 292,500 \\
& & 45,000 \\
& &
\end{tabular}

$1,456,100$

874,250

672,750

160,160

$3,163,260$

$-701,982$

$2,461,278$

$5,000,000$

75,000

25,000

2.272 
Figure 2. Transaction prices on non-agency RMBS through time.

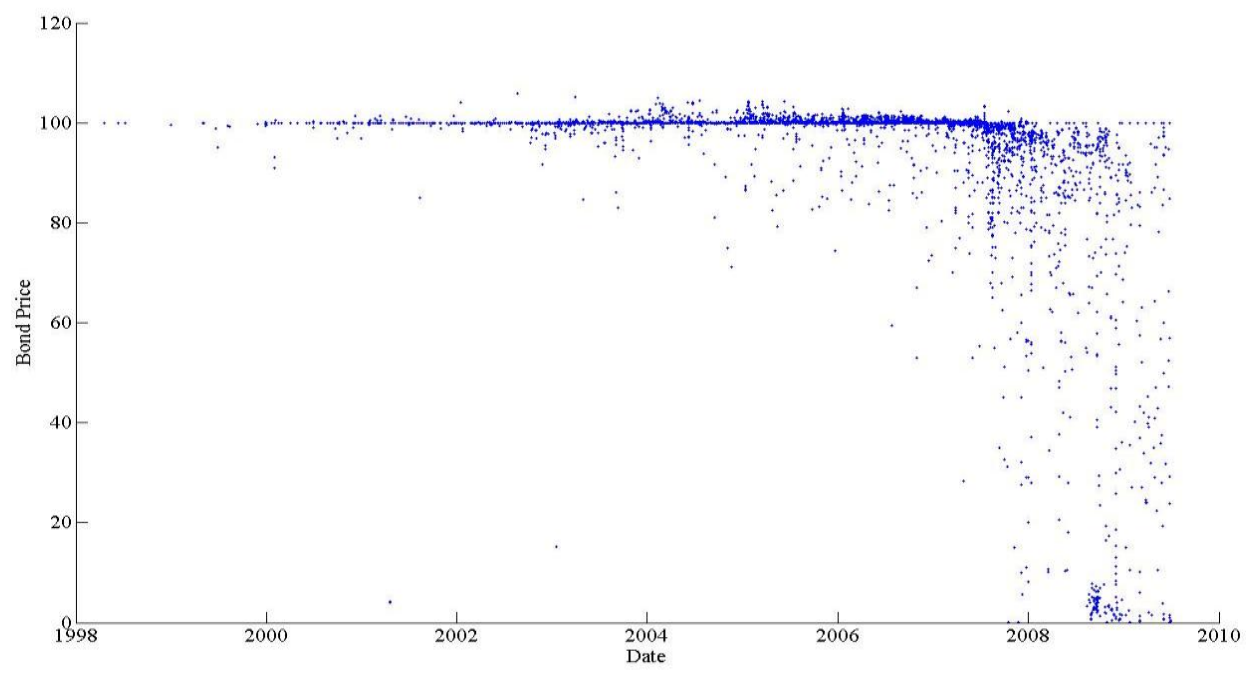


Figure 3. Frequency of RMBS transactions during the sample period.

This figure plots the 3-month moving average of the total number of non-agency RMBS transactions. The sample of transactions includes RMBS held on the balance sheets of both $\mathrm{P} \& \mathrm{C}$ and life insurance companies.

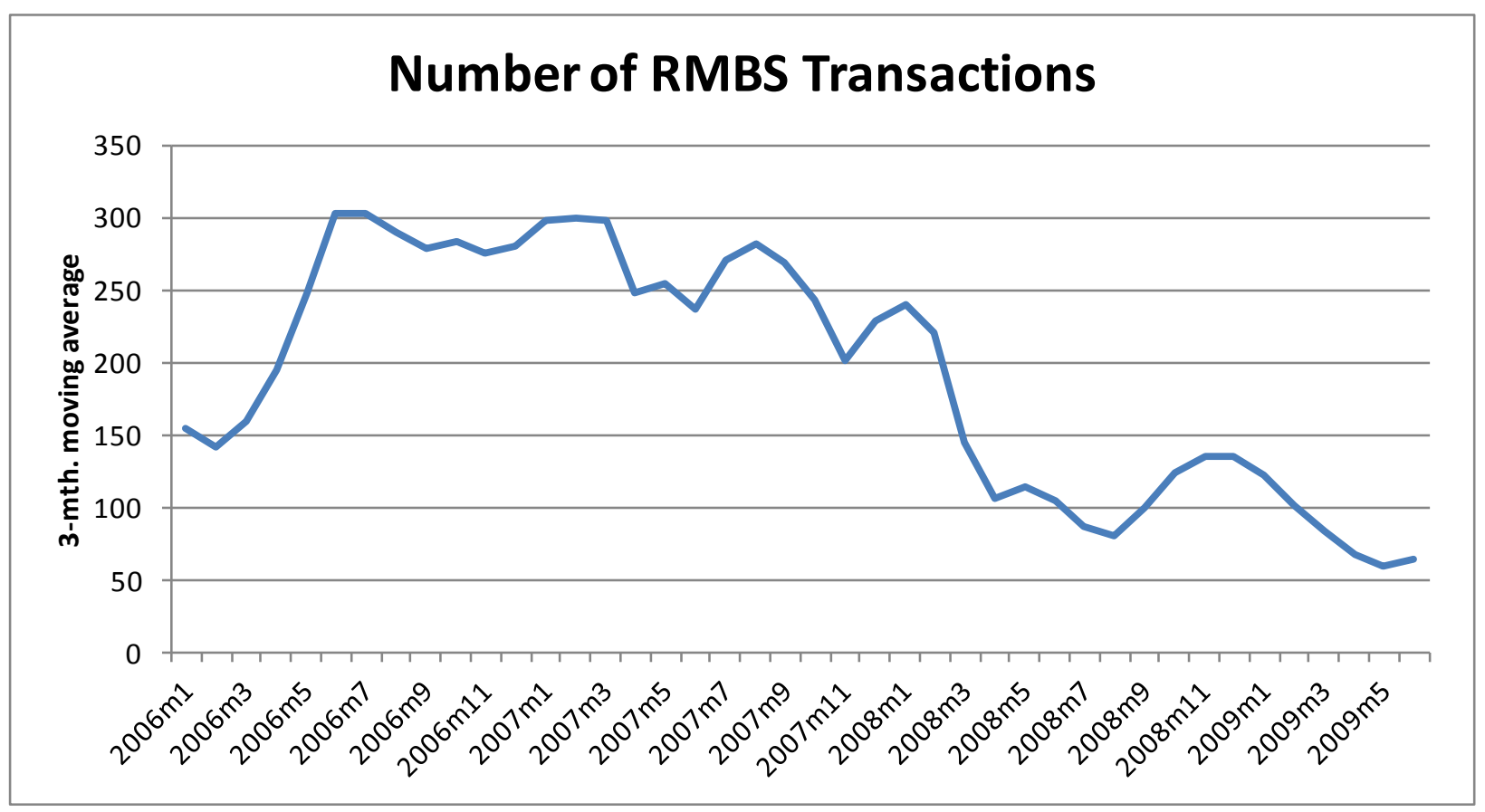


Figure 4. Sales and purchases of RMBS through the sample period.

This figure plots the 3-month moving average of the total number of non-agency RMBS transactions. The sample of transactions includes RMBS held on the balance sheets of P\&C and life insurance companies. We plot the number of sales and purchases separately.

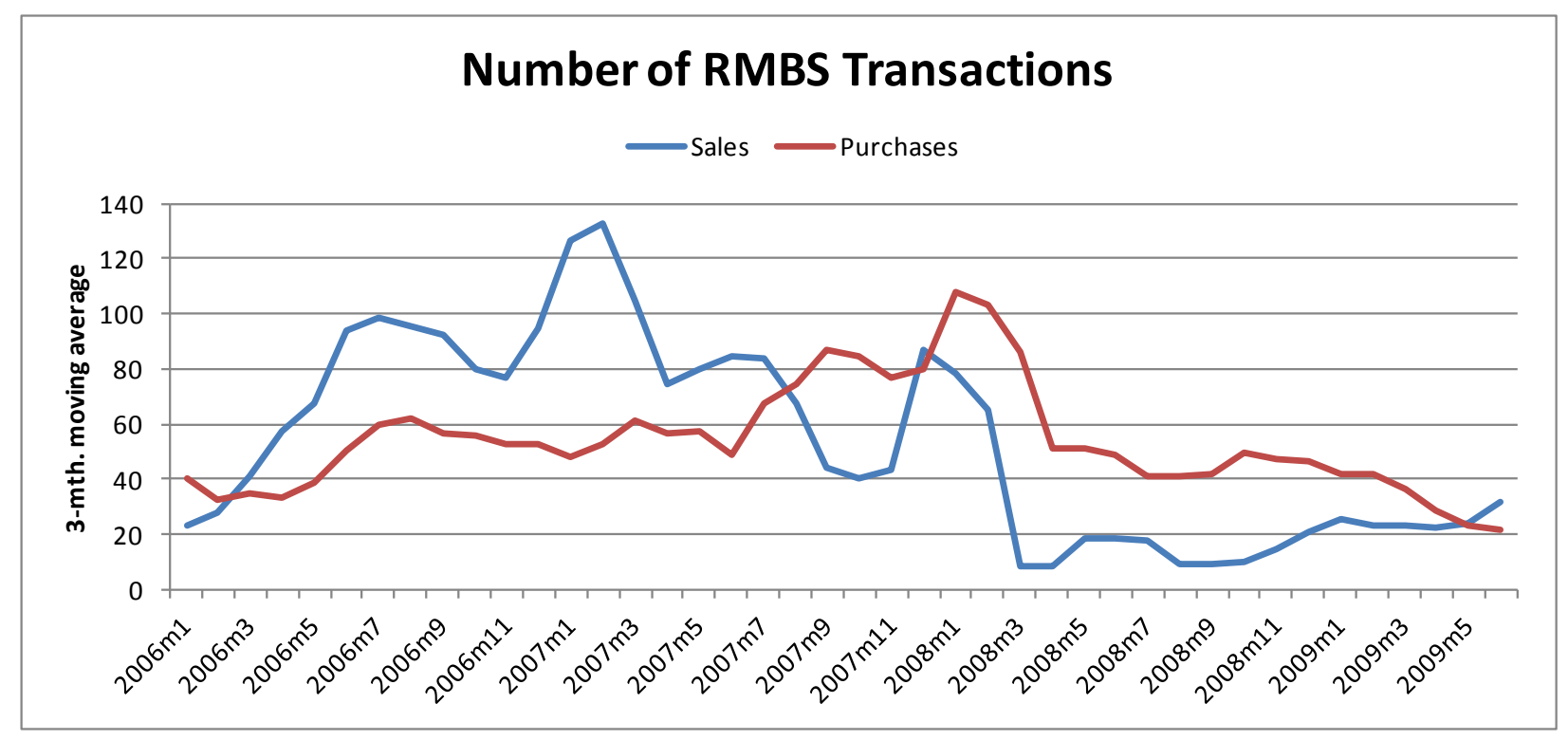


Table 1. Summary Statistics.

The RMBS transaction sample includes RMBS's held on the balance sheet of life and P\&C insurance companies. The sample includes bonds with at least two transactions, where the second transaction occurred during the years 2006 - September 2009. The variable "chg price" calculates the change in transaction price on the same RMBS from the first transaction to the second. The data classify each transaction as a "purchase" or a "sale." We classify insurance companies as being more likely to be capital constrained if the insurance company has experienced negative operating cash flow in a given year. Operating cash flow does not include gains or losses on account of a change in the market value of the non-agency RMBS held on insurance company's balance sheet. We report attributes of the mortgage collateral supporting the RMBS at the time of the second transaction.

\begin{tabular}{|c|c|c|c|c|c|c|c|c|}
\hline \multirow[b]{2}{*}{ Year, Qtr } & \multirow[b]{2}{*}{$\mathrm{N}$} & \multicolumn{3}{|c|}{ Change in Bond Price from Prior Transaction } & \multirow[t]{2}{*}{$\begin{array}{c}\% \text { of Transactions } \\
\text { that are Sales }\end{array}$} & \multicolumn{2}{|c|}{$\begin{array}{c}\% \text { of Transactions Associated } \\
\text { with Negative Operating Cash } \\
\text { Flow }\end{array}$} & \multirow[t]{2}{*}{$\begin{array}{c}\text { Mortgage Collateral } \\
\text { Default Rate in Month } \\
\text { Prior to Observed } \\
\text { Transaction } \\
\end{array}$} \\
\hline & & Average & Median & Std. Dev. & & Life & $\mathrm{P} \& \mathrm{C}$ & \\
\hline 2006 Q1 & 451 & $-0.13 \%$ & $0.00 \%$ & $4.04 \%$ & $58.98 \%$ & $30.74 \%$ & $16.20 \%$ & $4.08 \%$ \\
\hline 2006 Q2 & 497 & $-0.21 \%$ & $0.00 \%$ & $5.11 \%$ & $66.00 \%$ & $39.12 \%$ & $10.34 \%$ & $4.16 \%$ \\
\hline 2006 Q3 & 487 & $0.88 \%$ & $0.00 \%$ & $9.46 \%$ & $61.81 \%$ & $27.60 \%$ & $14.00 \%$ & $5.17 \%$ \\
\hline 2006 Q4 & 468 & $-3.34 \%$ & $0.00 \%$ & $13.51 \%$ & $64.10 \%$ & $33.66 \%$ & $16.98 \%$ & $6.08 \%$ \\
\hline 2007 Q1 & 541 & $-0.30 \%$ & $0.00 \%$ & $2.26 \%$ & $65.99 \%$ & $37.82 \%$ & $20.00 \%$ & $5.65 \%$ \\
\hline 2007 Q2 & 421 & $-1.21 \%$ & $-0.19 \%$ & $4.15 \%$ & $62.95 \%$ & $49.23 \%$ & $8.16 \%$ & $6.85 \%$ \\
\hline 2007 Q3 & 428 & $-3.10 \%$ & $-0.79 \%$ & $7.19 \%$ & $35.28 \%$ & $42.48 \%$ & $18.85 \%$ & $7.79 \%$ \\
\hline 2007 Q4 & 517 & $-4.78 \%$ & $-0.56 \%$ & $15.44 \%$ & $51.64 \%$ & $33.13 \%$ & $18.27 \%$ & $8.01 \%$ \\
\hline 2008 Q1 & 287 & $-14.86 \%$ & $-6.95 \%$ & $18.91 \%$ & $8.71 \%$ & $5.04 \%$ & $6.12 \%$ & $8.58 \%$ \\
\hline 2008 Q2 & 211 & $-14.62 \%$ & $-6.00 \%$ & $21.85 \%$ & $29.38 \%$ & $18.49 \%$ & $7.69 \%$ & $10.59 \%$ \\
\hline 2008 Q3 & 157 & $-20.54 \%$ & $-12.51 \%$ & $26.23 \%$ & $18.47 \%$ & $15.24 \%$ & $13.46 \%$ & $9.95 \%$ \\
\hline 2008 Q4 & 209 & $-41.37 \%$ & $-31.04 \%$ & $39.42 \%$ & $32.54 \%$ & $33.86 \%$ & $18.29 \%$ & $14.96 \%$ \\
\hline 2009 Q1 & 177 & $-23.67 \%$ & $-11.56 \%$ & $32.50 \%$ & $38.42 \%$ & $41.23 \%$ & $26.98 \%$ & $12.00 \%$ \\
\hline 2009 Q2 & 163 & $-35.08 \%$ & $-31.38 \%$ & $41.88 \%$ & $59.51 \%$ & $43.48 \%$ & $23.94 \%$ & $19.19 \%$ \\
\hline Aggregate Average & 5014 & $-6.95 \%$ & $-0.15 \%$ & $20.06 \%$ & $51.54 \%$ & $33.33 \%$ & $15.67 \%$ & $7.44 \%$ \\
\hline
\end{tabular}


Table 2. Hazard Model: Likelihood of Selling RMBS.

This table presents the results of a Cox proportional hazard model which estimates the likelihood of selling an RMBS following an observed purchase. We track the monthly, real-time collateral attributes of any given RMBS following an observed purchase between 2006-2008. The model estimates a baseline hazard through time, where a sale represents failure. Above and below-median capital firms are sorted based on an annual calculation of the median risk-based capital ratio (RBC) for $\mathrm{P} \& \mathrm{C}$ and life firms, respectively. Each of the measures of collateral quality measure real-time attributes of the mortgage collateral generating the RMBS cash flows. We cluster standard errors by month and report estimated coefficients as opposed to estimated hazard ratios.

\begin{tabular}{|c|c|c|c|c|c|}
\hline \multicolumn{6}{|c|}{$\begin{array}{l}\text { Cox Proportional Hazard Model: Propensity to Sell RMBS Following Observed Purchase } \\
\text { Sample: } 2006 \text { - } 2008 \\
\text { Note: Coefficients Reported (Not Hazard Ratios) }\end{array}$} \\
\hline & $\begin{array}{l}\text { P\&C and Life Sample } \\
\text { (1) }\end{array}$ & $\begin{array}{c}\text { P\&C Sample } \\
\text { (2) }\end{array}$ & $\begin{array}{l}\text { P\&C Sample } \\
\text { (3) }\end{array}$ & $\begin{array}{l}\text { Life Sample } \\
\text { (4) }\end{array}$ & $\begin{array}{c}\text { Life Sample } \\
\text { (5) }\end{array}$ \\
\hline Property \& Casualty Indicator & $\begin{array}{c}0.394 * * \\
(2.365)\end{array}$ & & & & \\
\hline Below-Median Risk-Based Capital Ratio & & $\begin{array}{c}0.477 * * \\
(2.302)\end{array}$ & $\begin{array}{l}0.557^{*} \\
(1.781)\end{array}$ & $\begin{array}{c}0.054 \\
(0.219)\end{array}$ & $\begin{array}{c}-0.100 \\
(-0.320)\end{array}$ \\
\hline Below-Median Risk-Based Capital Ratio* Default Rate & & & $\begin{array}{c}-1.354 \\
(-0.523)\end{array}$ & & $\begin{array}{c}2.308 \\
(1.163)\end{array}$ \\
\hline \multicolumn{6}{|l|}{ Deal-Level Measures of Collateral Quality: } \\
\hline Default Rate month $t-1$ & $\begin{array}{c}-4.121 * * * \\
(-4.851)\end{array}$ & $\begin{array}{c}-6.624 * * * \\
(-3.099)\end{array}$ & $\begin{array}{c}-5.816^{* *} * \\
(-2.510)\end{array}$ & $\begin{array}{c}-3.162 * * * \\
(-3.321)\end{array}$ & $\begin{array}{c}-4.137 * * * \\
(-2.645)\end{array}$ \\
\hline Cumulative House Price Appreciation & $\begin{array}{c}0.018^{* * * *} \\
(4.959)\end{array}$ & $\begin{array}{l}0.012^{*} \\
(1.735)\end{array}$ & $\begin{array}{l}0.012^{*} \\
(1.730)\end{array}$ & $\begin{array}{c}0.019 * * * \\
(4.878)\end{array}$ & $\begin{array}{c}0.019 * * * \\
(4.874)\end{array}$ \\
\hline Mortgage Rate & $\begin{array}{l}0.068 \\
(1.576)\end{array}$ & $\begin{array}{c}0.111 \\
(1.366)\end{array}$ & $\begin{array}{c}0.111 \\
(1.370)\end{array}$ & $\begin{array}{c}0.051 \\
(1.237)\end{array}$ & $\begin{array}{c}0.047 \\
(1.123)\end{array}$ \\
\hline FICO Score & $\begin{array}{c}0.000 \\
(0.242)\end{array}$ & $\begin{array}{c}-0.000 \\
(-0.239)\end{array}$ & $\begin{array}{c}-0.001 \\
(-0.249)\end{array}$ & $\begin{array}{c}0.001 \\
(0.384)\end{array}$ & $\begin{array}{c}0.001 \\
(0.455)\end{array}$ \\
\hline Combined Loan-to-Value Ratio & $\begin{array}{c}0.015 \\
(1.348)\end{array}$ & $\begin{array}{c}0.007 \\
(0.329)\end{array}$ & $\begin{array}{c}0.007 \\
(0.342)\end{array}$ & $\begin{array}{l}0.020^{*} \\
(1.697)\end{array}$ & $\begin{array}{l}0.020 * \\
(1.697)\end{array}$ \\
\hline Percentage of A.R.M.'s & $\begin{array}{c}0.654 * * * \\
(3.641)\end{array}$ & $\begin{array}{c}0.785 * * \\
(2.136)\end{array}$ & $\begin{array}{l}0.784 * * \\
(2.133)\end{array}$ & $\begin{array}{c}0.559 * * * \\
(3.273)\end{array}$ & $\begin{array}{c}0.549 * * * \\
(3.293)\end{array}$ \\
\hline Percent of Loans Owner Occupied & $\begin{array}{c}1.143 * * * \\
(2.936)\end{array}$ & $\begin{array}{l}1.344^{*} \\
(1.759)\end{array}$ & $\begin{array}{l}1.335^{*} \\
(1.764)\end{array}$ & $\begin{array}{c}0.992 * * * \\
(2.666)\end{array}$ & $\begin{array}{c}1.003^{*} * * \\
(2.721)\end{array}$ \\
\hline Percent of Loans No Doc./Low Doc. & $\begin{array}{l}0.489 * \\
(1.732)\end{array}$ & $\begin{array}{c}-0.178 \\
(-0.434)\end{array}$ & $\begin{array}{c}-0.176 \\
(-0.429)\end{array}$ & $\begin{array}{c}0.682 * * \\
(2.065)\end{array}$ & $\begin{array}{l}0.669 * * \\
(2.041)\end{array}$ \\
\hline Percent of Refinance Loans & $\begin{array}{c}-0.336 \\
(-1.290)\end{array}$ & $\begin{array}{c}-0.054 \\
(-0.0826)\end{array}$ & $\begin{array}{c}-0.042 \\
(-0.0647)\end{array}$ & $\begin{array}{c}-0.395 \\
(-1.290)\end{array}$ & $\begin{array}{c}-0.407 \\
(-1.331)\end{array}$ \\
\hline Cluster Standard Errors by Month & Yes & Yes & Yes & Yes & Yes \\
\hline Number of Subjects: & 8867 & 1996 & 1996 & 6721 & 6721 \\
\hline Number of Failures (Sales): & 1185 & 311 & 311 & 849 & 849 \\
\hline Total Number of Obs. & 211610 & 41159 & 41159 & 167094 & 167094 \\
\hline Log likelihood & -9745.1 & -2063.5 & -2063.2 & -6776.9 & -6774.4 \\
\hline Prob $>x^{2}$ & 0.000 & 0.000 & 0.000 & 0.000 & 0.000 \\
\hline
\end{tabular}


Table 3. RMBS Pricing: Property and Casualty Summary Statistics

This table reports summary statistics on repeat RMBS transactions for P\&C insurance companies. The sample period includes bonds with at least two transactions, where the second transaction occurred during the years 2006 September 2009. The variable "chg price" calculates the change in transaction price on the same RMBS from the first transaction to the second. The data classify each transaction as a "purchase" or a "sale." Above and belowmedian RBC firms are sorted based on an annual calculation of the median risk-based capital ratio (RBC) for P\&C firms. Panel B splits the sample based on whether transactions were associated with collateral that had above or below-median collateral default rates. We calculate collateral default rates as being above or below-median based on the collateral default rate at the time of the second transaction. The median default calculation uses the full sample of repeat sales from 2006-September 2009.

Panel A

\begin{tabular}{|c|c|c|c|c|c|c|c|c|}
\hline \multirow[b]{4}{*}{ Year, Qtr } & \multicolumn{4}{|c|}{ Full Sample } & \multicolumn{4}{|c|}{ Sales-Only Sample } \\
\hline & \multicolumn{2}{|r|}{$(1)$} & \multicolumn{2}{|r|}{ (2) } & \multicolumn{2}{|r|}{ (3) } & \multirow{2}{*}{\multicolumn{2}{|c|}{ Below-Median RBC }} \\
\hline & \multicolumn{2}{|c|}{ Above-Median RBC } & \multicolumn{2}{|c|}{ Below-Median RBC } & \multicolumn{2}{|c|}{ Above-Median RBC } & & \\
\hline & $\mathrm{N}$ & $\%$ chg in price & $\mathrm{N}$ & $\%$ chg in price & $\mathrm{N}$ & $\%$ chg in price & $\mathrm{N}$ & $\%$ chg in price \\
\hline 2006 Q1 & 60 & $-0.45 \%$ & 82 & $-0.41 \%$ & 33 & $-0.45 \%$ & 45 & $-0.68 \%$ \\
\hline 2006 Q2 & 120 & $-0.04 \%$ & 80 & $0.70 \%$ & 90 & $0.15 \%$ & 62 & $0.94 \%$ \\
\hline 2006 Q3 & 82 & $6.40 \%$ & 67 & $-0.52 \%$ & 63 & $8.51 \%$ & 41 & $-0.65 \%$ \\
\hline 2006 Q4 & 100 & $-13.98 \%$ & 57 & $0.45 \%$ & 71 & $-19.08 \%$ & 30 & $0.15 \%$ \\
\hline 2007 Q1 & 51 & $-0.71 \%$ & 58 & $0.09 \%$ & 27 & $-1.24 \%$ & 40 & $0.08 \%$ \\
\hline 2007 Q2 & 51 & $-0.95 \%$ & 46 & $-0.42 \%$ & 29 & $-1.40 \%$ & 32 & $-0.58 \%$ \\
\hline 2007 Q3 & 62 & $-2.20 \%$ & 60 & $-2.90 \%$ & 23 & $-3.91 \%$ & 35 & $-2.71 \%$ \\
\hline 2007 Q4 & 86 & $-2.12 \%$ & 97 & $-3.60 \%$ & 48 & $-1.75 \%$ & 47 & $-1.49 \%$ \\
\hline 2008 Q1 & 38 & $-10.07 \%$ & 11 & $-6.88 \%$ & 4 & $-4.92 \%$ & 3 & $0.68 \%$ \\
\hline 2008 Q2 & 27 & $-11.38 \%$ & 37 & $-14.73 \%$ & 3 & $-1.90 \%$ & 22 & $-21.07 \%$ \\
\hline 2008 Q3 & 31 & $-21.47 \%$ & 21 & $-27.77 \%$ & 3 & $-38.22 \%$ & 4 & $-34.37 \%$ \\
\hline $2008 Q^{4}$ & 41 & $-29.19 \%$ & 36 & $-49.28 \%$ & 5 & $-65.83 \%$ & 14 & $-47.28 \%$ \\
\hline 2009 Q1 & 23 & $-10.96 \%$ & 36 & $-41.50 \%$ & 9 & $-2.63 \%$ & 28 & $-39.14 \%$ \\
\hline 2009 Q2 & 40 & $-22.09 \%$ & 28 & $-26.68 \%$ & 14 & $-31.04 \%$ & 23 & $-29.25 \%$ \\
\hline Aggregate Average & 812 & $-6.15 \%$ & 716 & $-8.02 \%$ & 422 & $-4.73 \%$ & 426 & $-7.52 \%$ \\
\hline
\end{tabular}


Panel B.

\begin{tabular}{|c|c|c|c|c|c|c|c|c|}
\hline \multirow[b]{4}{*}{ Year, Qtr } & \multicolumn{4}{|c|}{ Above-Median Defaults, Sales-Only Sample } & \multicolumn{4}{|c|}{ Below-Median Defaults, Sales-Only Sample } \\
\hline & \multirow{2}{*}{\multicolumn{2}{|c|}{ Above-Median RBC }} & \multirow{2}{*}{\multicolumn{2}{|c|}{ Below-Median RBC }} & \multirow{2}{*}{\multicolumn{2}{|c|}{ Above-Median RBC }} & \multirow{2}{*}{\multicolumn{2}{|c|}{ Below-Median RBC }} \\
\hline & & & & & & & & \\
\hline & $\mathrm{N}$ & $\%$ chg in price & $\mathrm{N}$ & $\%$ chg in price & $\mathrm{N}$ & $\%$ chg in price & $\mathrm{N}$ & $\%$ chg in price \\
\hline 2006 Q1 & 9 & $-0.94 \%$ & 16 & $1.01 \%$ & 24 & $-0.27 \%$ & 29 & $-1.61 \%$ \\
\hline 2006 Q2 & 36 & $0.41 \%$ & 21 & $0.35 \%$ & 54 & $-0.03 \%$ & 41 & $1.24 \%$ \\
\hline 2006 Q3 & 20 & $2.21 \%$ & 12 & $-0.25 \%$ & 43 & $11.44 \%$ & 29 & $-0.82 \%$ \\
\hline 2006 Q4 & 21 & $-0.40 \%$ & 11 & $0.15 \%$ & 50 & $-26.92 \%$ & 19 & $0.14 \%$ \\
\hline 2007 Q1 & 17 & $-1.99 \%$ & 25 & $0.07 \%$ & 10 & $0.04 \%$ & 15 & $0.10 \%$ \\
\hline 2007 Q2 & 19 & $0.70 \%$ & 18 & $-0.67 \%$ & 10 & $-5.40 \%$ & 14 & $-0.47 \%$ \\
\hline $2007 \mathrm{Q} 3$ & 13 & $-7.11 \%$ & 24 & $-3.38 \%$ & 10 & $0.25 \%$ & 11 & $-1.25 \%$ \\
\hline $2007 \mathrm{Q} 4$ & 24 & $-2.41 \%$ & 26 & $-2.32 \%$ & 24 & $-1.10 \%$ & 21 & $-0.47 \%$ \\
\hline 2008 Q1 & 2 & $-3.71 \%$ & 3 & $0.68 \%$ & 2 & $-6.14 \%$ & 0 & $0.00 \%$ \\
\hline $2008 \mathrm{Q} 2$ & 1 & $-7.98 \%$ & 16 & $-26.85 \%$ & 2 & $1.14 \%$ & 6 & $-5.64 \%$ \\
\hline 2008 Q3 & 2 & $-8.93 \%$ & 4 & $-34.37 \%$ & 1 & $-96.79 \%$ & 0 & $0.00 \%$ \\
\hline $2008 \mathrm{Q} 4$ & 5 & $-65.83 \%$ & 14 & $-47.28 \%$ & 3 & $11.64 \%$ & 0 & $0.00 \%$ \\
\hline 2009 Q1 & 6 & $-9.77 \%$ & 20 & $-50.38 \%$ & 0 & $0.00 \%$ & 8 & $-11.04 \%$ \\
\hline $2009 \mathrm{Q} 2$ & 11 & $-29.61 \%$ & 20 & $-37.75 \%$ & 3 & $-36.27 \%$ & 3 & $27.43 \%$ \\
\hline Aggregate Average & 186 & $-4.71 \%$ & 230 & $-13.56 \%$ & 236 & $-4.75 \%$ & 196 & $-0.44 \%$ \\
\hline
\end{tabular}


Table 4. RMBS Pricing: Life Insurance Summary Statistics

This table reports summary statistics on repeat RMBS transactions for life insurance companies. The sample period includes RMBS with at least two transactions, where the second transaction occurred during the years 2006 -

September 2009. The variable "chg price" calculates the change in transaction price on the same RMBS from the first transaction to the second. The data classify each transaction as a "purchase" or a "sale." Above and belowmedian RBC firms are sorted based on an annual calculation of the median risk-based capital ratio (RBC) for Life firms. Panel B splits the sample based on whether transactions were associated with collateral that had above or below-median collateral default rates. We calculate collateral default rates as being above or below-median based on the collateral default rate at the time of the second transaction. The median default calculation uses the full sample of repeat sales transactions, from 2006-September 2009.

\section{Panel A}

\begin{tabular}{|c|c|c|c|c|c|c|c|c|}
\hline \multirow[b]{4}{*}{ Year, Qtr } & \multicolumn{4}{|c|}{ Full Sample } & \multicolumn{4}{|c|}{ Sales-Only Sample } \\
\hline & & (1) & \multirow{2}{*}{\multicolumn{2}{|c|}{ Below-Median RBC }} & \multirow{2}{*}{\multicolumn{2}{|c|}{ Above-Median RBC }} & \multirow{2}{*}{\multicolumn{2}{|c|}{ Below-Median RBC }} \\
\hline & \multicolumn{2}{|c|}{ Above-Median RBC } & & & & & & \\
\hline & $\mathrm{N}$ & $\%$ chg in price & $\mathrm{N}$ & $\%$ chg in price & $\mathrm{N}$ & $\%$ chg in price & $\mathrm{N}$ & $\%$ chg in price \\
\hline 2006 Q1 & 139 & $-0.06 \%$ & 165 & $0.10 \%$ & 87 & $0.10 \%$ & 101 & $-0.43 \%$ \\
\hline 2006 Q2 & 131 & $-0.52 \%$ & 159 & $-0.57 \%$ & 83 & $-0.55 \%$ & 88 & $-0.69 \%$ \\
\hline 2006 Q3 & 150 & $-0.13 \%$ & 184 & $-0.18 \%$ & 81 & $0.01 \%$ & 114 & $-0.32 \%$ \\
\hline 2006 Q4 & 139 & $-0.31 \%$ & 167 & $-0.85 \%$ & 65 & $-0.77 \%$ & 130 & $-1.09 \%$ \\
\hline 2007 Q1 & 279 & $-0.16 \%$ & 148 & $-0.56 \%$ & 194 & $-0.27 \%$ & 93 & $-0.88 \%$ \\
\hline 2007 Q2 & 123 & $-1.55 \%$ & 194 & $-1.29 \%$ & 63 & $-2.87 \%$ & 134 & $-1.59 \%$ \\
\hline 2007 Q3 & 208 & $-3.60 \%$ & 97 & $-2.74 \%$ & 60 & $-4.63 \%$ & 33 & $-4.22 \%$ \\
\hline 2007 Q4 & 106 & $-4.85 \%$ & 209 & $-6.85 \%$ & 40 & $-4.16 \%$ & 116 & $0.27 \%$ \\
\hline 2008 Q1 & 173 & $-18.95 \%$ & 64 & $-8.22 \%$ & 6 & $-34.51 \%$ & 12 & $-9.35 \%$ \\
\hline 2008 Q2 & 52 & $-10.02 \%$ & 92 & $-18.45 \%$ & 12 & $-27.82 \%$ & 23 & $-32.49 \%$ \\
\hline 2008 Q3 & 33 & $-22.49 \%$ & 72 & $-17.14 \%$ & 5 & $-81.91 \%$ & 17 & $-31.12 \%$ \\
\hline 2008 Q4 & 67 & $-60.56 \%$ & 60 & $-25.14 \%$ & 37 & $-86.76 \%$ & 12 & $-53.38 \%$ \\
\hline 2009 Q1 & 45 & $-29.32 \%$ & 69 & $-16.93 \%$ & 10 & $-44.61 \%$ & 21 & $-33.47 \%$ \\
\hline 2009 Q2 & 59 & $-48.41 \%$ & 32 & $-38.24 \%$ & 42 & $-55.79 \%$ & 18 & $-60.53 \%$ \\
\hline Aggregate Average & 1704 & $-8.46 \%$ & 1712 & $-5.63 \%$ & 785 & $-9.82 \%$ & 912 & $-4.94 \%$ \\
\hline
\end{tabular}




\section{Panel B}

\begin{tabular}{|c|c|c|c|c|c|c|c|c|}
\hline \multirow[b]{4}{*}{ Year, Qtr } & \multicolumn{4}{|c|}{ Above-Median Defaults, Sales-Only Sample } & \multicolumn{4}{|c|}{ Below-Median Defaults, Sales-Only Sample } \\
\hline & & $(5)$ & \multirow{2}{*}{\multicolumn{2}{|c|}{ Below-Median RBC }} & \multirow{2}{*}{\multicolumn{2}{|c|}{ Above-Median RBC }} & \multirow{2}{*}{\multicolumn{2}{|c|}{$\frac{(8)}{\text { Below-Median RBC }}$}} \\
\hline & \multicolumn{2}{|c|}{ Above-Median RBC } & & & & & & \\
\hline & $\mathrm{N}$ & $\%$ chg in price & $\mathrm{N}$ & $\%$ chg in price & $\mathrm{N}$ & $\%$ chg in price & $\mathrm{N}$ & $\%$ chg in price \\
\hline 2006 Q1 & 43 & $0.30 \%$ & 39 & $-0.32 \%$ & 44 & $-0.09 \%$ & 62 & $-0.50 \%$ \\
\hline 2006 Q2 & 23 & $-0.71 \%$ & 33 & $-0.25 \%$ & 60 & $-0.48 \%$ & 55 & $-0.95 \%$ \\
\hline 2006 Q3 & 48 & $-0.06 \%$ & 53 & $-0.27 \%$ & 33 & $0.10 \%$ & 61 & $-0.37 \%$ \\
\hline 2006 Q4 & 30 & $-1.13 \%$ & 70 & $-1.56 \%$ & 35 & $-0.46 \%$ & 60 & $-0.55 \%$ \\
\hline 2007 Q1 & 118 & $-0.33 \%$ & 70 & $-1.10 \%$ & 76 & $-0.17 \%$ & 23 & $-0.21 \%$ \\
\hline 2007 Q2 & 44 & $-3.50 \%$ & 87 & $-1.88 \%$ & 19 & $-1.41 \%$ & 47 & $-1.03 \%$ \\
\hline 2007 Q3 & 43 & $-6.19 \%$ & 17 & $-4.79 \%$ & 17 & $-0.67 \%$ & 16 & $-3.62 \%$ \\
\hline 2007 Q4 & 23 & $-3.51 \%$ & 78 & $-0.35 \%$ & 17 & $-5.05 \%$ & 38 & $1.55 \%$ \\
\hline 2008 Q1 & 4 & $-51.33 \%$ & 8 & $-14.10 \%$ & 2 & $-0.85 \%$ & 4 & $0.14 \%$ \\
\hline 2008 Q2 & 10 & $-33.23 \%$ & 16 & $-45.73 \%$ & 2 & $-0.79 \%$ & 7 & $-2.23 \%$ \\
\hline 2008 Q3 & 5 & $-81.91 \%$ & 15 & $-34.66 \%$ & 0 & $0.00 \%$ & 2 & $-4.54 \%$ \\
\hline 2008 Q 4 & 34 & $-93.72 \%$ & 11 & $-55.21 \%$ & 3 & $-7.86 \%$ & 1 & $-33.30 \%$ \\
\hline 2009 Q1 & 9 & $-46.76 \%$ & 13 & $-36.10 \%$ & 1 & $-25.26 \%$ & 8 & $-29.19 \%$ \\
\hline 2009 Q2 & 37 & $-63.67 \%$ & 17 & $-63.96 \%$ & 5 & $2.44 \%$ & 1 & $-2.35 \%$ \\
\hline Aggregate Average & 471 & $-15.90 \%$ & 527 & $-7.63 \%$ & 314 & $-0.71 \%$ & 385 & $-1.26 \%$ \\
\hline
\end{tabular}


Table 5. Are the Sales of Constrained Firms Associated with Pricing Discounts?

The dependent variable in this OLS estimation is the change in price on a given RMBS between two transactions, where the second transaction occurred in the years 2006 - September 2009. We classify insurance companies as having experienced an adverse shock to their capital if the insurance company has experienced negative operating cash flow in the year of the transaction. Operating cash flow does not include gains or losses on account of a change in the market value of the non-agency RMBS held on insurance company's balance sheet. We measure RMBS fundamentals using the change in the collateral attributes from the prior transaction to the current transaction. We create an indicator variable for sales. The model includes quarter fixed-effects, and the interaction of quarter fixed effects with a variable which measures the number of months from the prior transaction. We cluster standard errors by month of the second transaction.

\begin{tabular}{|c|c|c|c|c|c|c|}
\hline & \multicolumn{6}{|c|}{ Dependent Variable: $\%$ Change in Price from Prior Transaction } \\
\hline & \multicolumn{2}{|c|}{ P \& C Insurers: 2006- Sep. 2009} & \multicolumn{2}{|c|}{ Life Insurers: 2006-2008 } & \multicolumn{2}{|c|}{ Life Insurers: 2009} \\
\hline & Neg. Op. Cash Flow & Pos. Op. Cash Flow & Neg. Op. Cash Flow & Pos. Op. Cash Flow & Neg. Op. Cash Flow & Pos. Op. Cash Flow \\
\hline & (1) & (2) & (3) & (4) & (5) & (6) \\
\hline Operating Cash/Capital * Sale Indicator & $\begin{array}{c}0.195^{* *} \\
(2.431)\end{array}$ & $\begin{array}{c}-0.049 \\
(-1.434)\end{array}$ & $\begin{array}{c}-0.001 \\
(-0.0685)\end{array}$ & $\begin{array}{c}0.002 \\
(0.245)\end{array}$ & $\begin{array}{c}0.246 * * \\
(2.981)\end{array}$ & $\begin{array}{c}0.055 \\
(0.735)\end{array}$ \\
\hline Operating Cash/Capital & $\begin{array}{c}-0.196^{* * *} \\
(-2.546)\end{array}$ & $\begin{array}{c}0.056^{* * *} \\
(2.311)\end{array}$ & $\begin{array}{c}-0.002 \\
(-0.149)\end{array}$ & $\begin{array}{l}0.011^{*} \\
(1.721)\end{array}$ & $\begin{array}{c}-0.136 \\
(-0.981)\end{array}$ & $\begin{array}{c}-0.042 \\
(-1.980)\end{array}$ \\
\hline Sale Indicator & $\begin{array}{c}0.026 \\
(0.748)\end{array}$ & $\begin{array}{c}-0.017 \\
(-1.209)\end{array}$ & $\begin{array}{c}-0.021 \\
(-1.416)\end{array}$ & $\begin{array}{c}-0.019 \\
(-0.983)\end{array}$ & $\begin{array}{c}0.071 \\
(0.708)\end{array}$ & $\begin{array}{c}-0.258^{* * *} \\
(-3.931)\end{array}$ \\
\hline \multicolumn{7}{|l|}{ Change in Collateral Quality from Prior Trade: } \\
\hline Chg. Default Rate ${ }_{\text {nonth t-1 }}$ & $\begin{array}{c}-1.535 * * * \\
(-3.236)\end{array}$ & $\begin{array}{c}-0.414 * * \\
(-2.161)\end{array}$ & $\begin{array}{c}-0.282 \\
(-1.372)\end{array}$ & $\begin{array}{c}-0.603 * * * \\
(-2.735)\end{array}$ & $\begin{array}{l}-0.687 \\
(-1.229)\end{array}$ & $\begin{array}{c}-1.728 * * * \\
(-4.736)\end{array}$ \\
\hline Chg. Cumulative House Price Appreciation & $\begin{array}{c}0.000 \\
(0.109)\end{array}$ & $\begin{array}{c}0.002 \\
(1.192)\end{array}$ & $\begin{array}{c}0.004 * * * \\
(3.247)\end{array}$ & $\begin{array}{c}0.004 * * * \\
(3.833)\end{array}$ & $\begin{array}{c}0.027 * * \\
(3.043)\end{array}$ & $\begin{array}{c}0.001 \\
(0.221)\end{array}$ \\
\hline Chg. Mortgage Rate & $\begin{array}{l}0.068^{*} \\
(1.774)\end{array}$ & $\begin{array}{c}0.066 * * * \\
(4.535)\end{array}$ & $\begin{array}{l}0.026^{* * *} \\
(2.279)\end{array}$ & $\begin{array}{c}0.015^{* * * *} \\
(2.928)\end{array}$ & $\begin{array}{c}0.007 \\
(0.141)\end{array}$ & $\begin{array}{c}0.026 \\
(1.249)\end{array}$ \\
\hline Chg. FICO Score & $\begin{array}{c}0.009 \\
(1.659)\end{array}$ & $\begin{array}{c}0.005^{* *} \\
(2.173)\end{array}$ & $\begin{array}{c}0.003 \\
(1.538)\end{array}$ & $\begin{array}{c}-0.001 \\
(-0.810)\end{array}$ & $\begin{array}{c}0.016 \\
(1.584)\end{array}$ & $\begin{array}{c}-0.009 \\
(-0.701)\end{array}$ \\
\hline Chg. Combined Loan-to-Value Ratio & $\begin{array}{l}0.020 \\
(0.684)\end{array}$ & $\begin{array}{c}-0.007 \\
(-0.614)\end{array}$ & $\begin{array}{c}-0.007 \\
(-0.937)\end{array}$ & $\begin{array}{l}0.005 \\
(0.489)\end{array}$ & $\begin{array}{c}0.031 \\
(0.943)\end{array}$ & $\begin{array}{c}-0.017 \\
(-0.974)\end{array}$ \\
\hline Chg. Percentage of A.R.M.'s & $\begin{array}{l}1.565^{*} \\
(1.746)\end{array}$ & $\begin{array}{c}0.373^{* *} \\
(2.300)\end{array}$ & $\begin{array}{c}0.196 \\
(1.126)\end{array}$ & $\begin{array}{c}-0.123 \\
(-1.075)\end{array}$ & $\begin{array}{c}0.807 \\
(1.568)\end{array}$ & $\begin{array}{c}-0.469 \\
(-0.591)\end{array}$ \\
\hline Chg. Percent of Loans Owner Occupied & $\begin{array}{c}0.700 \\
(0.711)\end{array}$ & $\begin{array}{c}0.340 \\
(0.876)\end{array}$ & $\begin{array}{c}-0.230 \\
(-0.565)\end{array}$ & $\begin{array}{c}-0.206 \\
(-0.686)\end{array}$ & $\begin{array}{c}3.525^{* * * *} \\
(6.432)\end{array}$ & $\begin{array}{c}1.976 \\
(1.029)\end{array}$ \\
\hline Chg. Percent of Loans No Doc./Low Doc. & $\begin{array}{c}-0.119 \\
(-0.109)\end{array}$ & $\begin{array}{c}-0.602 \\
(-1.418)\end{array}$ & $\begin{array}{c}0.217 \\
(0.885)\end{array}$ & $\begin{array}{c}-0.381 \\
(-1.314)\end{array}$ & $\begin{array}{c}0.872 \\
(1.039)\end{array}$ & $\begin{array}{c}-1.013 \\
(-0.468)\end{array}$ \\
\hline Chg. Percent of Refinance Loans & $\begin{array}{c}2.410 \\
(1.482)\end{array}$ & $\begin{array}{c}0.102 \\
(0.266)\end{array}$ & $\begin{array}{c}0.077 \\
(0.328)\end{array}$ & $\begin{array}{c}-0.227 \\
(-0.720)\end{array}$ & $\begin{array}{l}-1.901 \\
(-1.771)\end{array}$ & $\begin{array}{l}-1.394 * \\
(-2.372)\end{array}$ \\
\hline Months from Prior Trade & $\begin{array}{c}0.009 * * \\
(2.366)\end{array}$ & $\begin{array}{c}-0.003 \\
(-1.169)\end{array}$ & $\begin{array}{c}-0.015 \\
(-1.412)\end{array}$ & $\begin{array}{c}-0.005 * * * \\
(-3.532)\end{array}$ & $\begin{array}{c}0.012 * * \\
(2.800)\end{array}$ & $\begin{array}{c}0.00 \\
(0.00)\end{array}$ \\
\hline Chg. in 5-year T-Bond Rate & $\begin{array}{c}0.106^{* *} \\
(2.131)\end{array}$ & $\begin{array}{c}0.058^{* * * *} \\
(3.188)\end{array}$ & $\begin{array}{c}0.021 \\
(1.135)\end{array}$ & $\begin{array}{c}0.029 * * * \\
(2.770)\end{array}$ & $\begin{array}{c}-0.031 \\
(-0.683)\end{array}$ & $\begin{array}{c}0.054 \\
(1.825)\end{array}$ \\
\hline Constant & $\begin{array}{l}-0.065 \\
(-1.591)\end{array}$ & $\begin{array}{c}0.014 \\
(0.273)\end{array}$ & $\begin{array}{c}0.094 \\
(1.304)\end{array}$ & $\begin{array}{c}-0.016 \\
(-1.029)\end{array}$ & $\begin{array}{c}-0.031 \\
(-0.266)\end{array}$ & $\begin{array}{c}0.089 \\
(1.852)\end{array}$ \\
\hline Quarter Fixed Effects & Yes & Yes & Yes & Yes & Yes & Yes \\
\hline Quarter Fixed Effects * Months from Prior Trade & Yes & Yes & Yes & Yes & Yes & Yes \\
\hline Cluster Standard Errors by Month & Yes & Yes & Yes & Yes & Yes & Yes \\
\hline Observations & 241 & 1250 & 1055 & 2142 & 84 & 116 \\
\hline Adj. R2 & 0.683 & 0.435 & 0.655 & 0.437 & 0.846 & 0.609 \\
\hline
\end{tabular}


Table 6. Are the Pricing Discounts on Sales of Constrained Firms Larger for RMBS of Lower Credit Quality?

The dependent variable in this OLS estimation is the change in price on a given RMBS between two transactions, where the second transaction occurred in the years 2006 - September 2009. The sample in this table includes changes in prices where the second transaction was either a purchase or a sale. We create a separate indicator variable for sales. We classify insurance companies as having experienced an adverse shock to their capital if the insurance company has experienced negative operating cash flow in the year of the second transaction. We calculate collateral default rates as being above or below-median based on the collateral default rate at the time of the second transaction. The median default rate calculation uses the full sample of repeat sales transactions, from 2006September 2009. We measure RMBS fundamentals using the change in the collateral attributes from the prior transaction to the current transaction. The model includes quarter fixed-effects, and the interaction of quarter fixed effects with a variable which measures the number of months from the prior transaction. We cluster standard errors by the month of the second transaction.

\begin{tabular}{|c|c|c|c|}
\hline & \multicolumn{3}{|c|}{ Dependent Variable: \% Change in Price from Prior Transaction } \\
\hline & $\begin{array}{c}\text { P \& C Insurers: 2006- Sep. } 2009 \\
\text { Neg. Op. Cash Flow }\end{array}$ & $\begin{array}{l}\text { Life Insurers: 2006-2008 } \\
\text { Neg. Op. Cash Flow }\end{array}$ & $\begin{array}{l}\text { Life Insurers: } 2009 \\
\text { Neg. Op. Cash Flow }\end{array}$ \\
\hline & $(1)$ & $(2)$ & (3) \\
\hline Operating Cash/Capital $*$ Sales * Above-Median Defaults & $\begin{array}{c}0.291 * * * \\
(3.470)\end{array}$ & $\begin{array}{l}-0.020 \\
(-0.801)\end{array}$ & $\begin{array}{l}0.668^{*} \\
(1.807)\end{array}$ \\
\hline Operating Cash/Capital * Above-Median Defaults & $\begin{array}{c}-0.328 * * * \\
(-5.339)\end{array}$ & $\begin{array}{c}0.005 \\
(0.249)\end{array}$ & $\begin{array}{l}-0.154 \\
(-0.879)\end{array}$ \\
\hline Operating Cash/Capital $*$ Sale Indicator & $\begin{array}{c}0.010 \\
(0.271)\end{array}$ & $\begin{array}{c}0.012 \\
(0.652)\end{array}$ & $\begin{array}{l}-0.258 \\
(-0.903)\end{array}$ \\
\hline Sale Indicator * Above-Median Defaults & $\begin{array}{c}0.026 \\
(0.295)\end{array}$ & $\begin{array}{c}-0.060^{* *} * \\
(-2.233)\end{array}$ & $\begin{array}{c}0.213 \\
(1.752)\end{array}$ \\
\hline Operating Cash/Capital & $\begin{array}{c}0.009 \\
(0.272)\end{array}$ & $\begin{array}{l}-0.007 \\
(-0.509)\end{array}$ & $\begin{array}{c}0.037 \\
(0.351)\end{array}$ \\
\hline Sale Indicator & $\begin{array}{c}0.004 \\
(0.0903)\end{array}$ & $\begin{array}{c}0.010 \\
(1.222)\end{array}$ & $\begin{array}{l}-0.083 \\
(-1.285)\end{array}$ \\
\hline Above-Median Defaults & $\begin{array}{l}-0.021 \\
(-0.254)\end{array}$ & $\begin{array}{l}0.033^{*} \\
(2.026)\end{array}$ & $\begin{array}{c}0.018 \\
(0.576)\end{array}$ \\
\hline \multicolumn{4}{|l|}{ Change in Collateral Quality from Prior Trade: } \\
\hline Chg. Cumulative House Price Appreciation & $\begin{array}{c}0.003 \\
(0.728)\end{array}$ & $\begin{array}{c}0.004 * * * \\
(3.201)\end{array}$ & $\begin{array}{l}0.024 * * \\
(2.855)\end{array}$ \\
\hline Chg. Mortgage Rate & $\begin{array}{c}0.054 \\
(1.396)\end{array}$ & $\begin{array}{l}0.022 * * \\
(2.184)\end{array}$ & $\begin{array}{c}0.037 \\
(0.763)\end{array}$ \\
\hline Chg. FICO Score & $\begin{array}{c}0.004 \\
(0.614)\end{array}$ & $\begin{array}{l}0.004^{*} \\
(1.965)\end{array}$ & $\begin{array}{c}0.033 * * * \\
(4.107)\end{array}$ \\
\hline Chg. Combined Loan-to-Value Ratio & $\begin{array}{c}-0.015 \\
(-0.528)\end{array}$ & $\begin{array}{l}-0.008 \\
(-1.319)\end{array}$ & $\begin{array}{c}0.015 \\
(0.399)\end{array}$ \\
\hline Chg. Percentage of A.R.M.'s & $\begin{array}{l}1.469 * \\
(1.892)\end{array}$ & $\begin{array}{l}0.316^{*} \\
(1.894)\end{array}$ & $\begin{array}{c}1.285 \\
(1.295)\end{array}$ \\
\hline Chg. Percent of Loans Owner Occupied & $\begin{array}{c}0.103 \\
(0.0732)\end{array}$ & $\begin{array}{l}-0.292 \\
(-0.715)\end{array}$ & $\begin{array}{r}3.324 * * \\
(3.777)\end{array}$ \\
\hline Chg. Percent of Loans No Doc./Low Doc. & $\begin{array}{c}1.136 \\
(0.864)\end{array}$ & $\begin{array}{c}0.329 \\
(1.197)\end{array}$ & $\begin{array}{c}1.205 \\
(1.742)\end{array}$ \\
\hline Chg. Percent of Refinance Loans & $\begin{array}{c}0.737 \\
(0.516)\end{array}$ & $\begin{array}{c}0.130 \\
(0.551)\end{array}$ & $\begin{array}{l}-2.025 \\
(-1.062)\end{array}$ \\
\hline Months from Prior Trade & $\begin{array}{r}0.014 * * \\
(2.697)\end{array}$ & $\begin{array}{l}-0.015 \\
(-1.492)\end{array}$ & $\begin{array}{c}0.007 \\
(1.680)\end{array}$ \\
\hline Chg. in 5-year T-Bond Rate & $\begin{array}{l}0.120 * * \\
(2.684)\end{array}$ & $\begin{array}{c}0.024 \\
(1.262)\end{array}$ & $\begin{array}{l}-0.021 \\
(-0.376)\end{array}$ \\
\hline Constant & $\begin{array}{c}-0.081 \\
(-1.601)\end{array}$ & $\begin{array}{c}0.077 \\
(0.995)\end{array}$ & $\begin{array}{c}-0.033 \\
(-0.339)\end{array}$ \\
\hline Quarter Fixed Effects & Yes & Yes & Yes \\
\hline Quarter Fixed Effects * Months from Prior Trade & Yes & Yes & Yes \\
\hline Cluster Standard Errors by Month & Yes & Yes & Yes \\
\hline $\begin{array}{l}\text { Observations } \\
\text { Adj. R2 }\end{array}$ & $\begin{array}{c}241 \\
0.681\end{array}$ & $\begin{array}{l}1055 \\
0.657\end{array}$ & $\begin{array}{c}84 \\
0.864\end{array}$ \\
\hline
\end{tabular}

